\title{
Queering the web archive: A xenofeminist approach to gender, function, language and culture in the London French Special Collection
}

Saskia Huc-Hepher (1) ${ }^{1 凶}$

\begin{abstract}
Based on the author's experience of curating a collection of migrant community web objects within the UK Web Archive, this paper combines conceptual interrogation with empirical analysis. The central premise is that the incorporation of multilingual, diasporic microarchives serves to queer the anglophone UK Web Archive, or "patriarchive", by dismantling steadfast binaries and implicit postcolonial hegemonies. The article challenges Jacques Derrida's contention that the mal d'archive is the result of the archive's 'troubling' duality, and posits, on the contrary, that such boundary-crossings are the very incarnation of a positive, transgressive form of xenofeminism (XF). From the dualism at the origin of the archive itself, to that comprised in the concept of genre/gender, and from the spatiotemporal inbetweenness of the archived diasporic (web)site to the translanguaging present therein, the article demonstrates how the diasporic micro-archive is the embodiment of a non-binary, trans-inclusive XF ideology. Taking French migrant women's blogs preserved in the London French Special Collection as a primary source and examining their transformation over time, the paper explores how blog repurposing can be apprehended as a technomaterialist XF act and how the blogs' increasing multimodal translanguaging bears witness to a form of culturolinguistic transitioning that transcends binary hybridity.
\end{abstract}

\footnotetext{
${ }^{1}$ School of Humanities, University of Westminster, London, UK. 凶email: S.V.Huc-Hepher@westminster.ac.uk
} 


\section{Introducing the archive through an XF lens}

he world's first web archive, the not-for-profit Internet Archive, was created in the United States in 1996, only 3 years after the public launch of the World Wide Web by the Conseil Européen pour la Recherche Nucléaire (better known as CERN). The Internet Archive has been taking, storing and sharing snapshots of the entire webosphere since that time, its mission being to produce a library of websites to enable 'Universal Access to All Knowledge' (Internet Archive, no date). Almost a decade later, concerned about the custodianship of UK resources held by the Internet Archive, the British Library began collecting webpages located in the UK domain to ensure their long-term preservation and accessibility (British Library, no date), while similar initiatives were being rolled out in other national libraries (Milligan, 2019). In an age of information abundance where the majority of new knowledge is mediated through borndigital, online channels but where 'we are forgetting to preserve the information that we generate' (Gomes, 2021, p. 2), web archives play a crucial role in transforming present-and intrinsically transient-internet data into the stuff of future memory. However, given the sheer scale of such archives (there are currently over 400 billion webpages in the Internet Archive (Costa, 2021)) and the elusiveness of the material stored due to search-functionality challenges, web archives threaten to be 'useless' (Costa, 2021, p. 71) repositories for 'stranded data' (Kitchin, 2014, p. 156, citing Singh, 2012). To minimise the paradoxical risk of web archives becoming the very digital 'black holes' they were built to prevent, the British Library developed its Special Collections. These Collections present users with thematically curated, downsized datasets, whose targeted scope makes them navigable and meaningful on a human level. It is within this context that I curated the London French Special Collection (LFSC) and that this article, in which I take a critical xenofeminist approach to the purportedly universal web archive, is situated.

Recent scholarship on the preservation of digital heritage and web archiving praxis underlines the need for a reflexive, critical approach which acknowledges the implications and implicatedness of practitioners, as well as the agency of the archive itself (BenDavid, 2021); the intrinsic materiality and ambiguity of web archives as both sources and subjects of knowledge (Ogden et al., 2017; Ogden and Maemura, 2021); and the disruptive potential of '[p]resenting collections as data' (Ames and Lewis, 2020, p. 3) and presenting web data as archives (Milligan, 2019). It urges researchers to combine the epistemological with the ontological, and the theoretical with the practical; for how, as Bonacchi and Krzyzanska ask, 'can we decolonise collections and disrupt dominant ways of organising and representing information, if we are not able to track the creation and circulation of data?' (2019, p. 1236) and if we lack the requisite pragmatic, cultural and linguistic insights? One way to begin decolonising digital data collections is by 'presencing women' and 're-voicing narratives' (Thompson, 2020, p. 1), while recognising the importance of women's translingual 'semiotic repertoires [online and] "on the move"' (Tagg and Lyons, 2021, p. 247; Kusters et al., 2017). ${ }^{1}$ Web archiving has, as Nicola Jayne Bingham and Helena Byrne of the British Library note, 'a unique opportunity' to do this, by 'represent[ing] communities that may be marginalised for various reasons' (Bingham and Byrne, 2020 , p. 4). Through my application of a xenofeminist lens to the LFSC and subsequent ethnosemiotic analysis of women migrants' web objects therein, I attend to all these concerns and contribute constructively to 'digital heritage activism' (Bonacchi and Krzyzanska, 2019, p. 1242), taking it in a previously unexplored direction. Furthermore, in the spirit of transdisciplinarity, I hope to make productive theoretical contributions to multiple fields: to Library and Information Studies, which can be overly practicefocused; to Gender Studies, through the figurative application of trans-inclusive ideology to a new object of enquiry; and to French Studies-and Modern Languages more broadly-by offering an analysis which acknowledges the value of French in a transnational, translingual, postcolonial, post-canonical and posthuman context.

I began curating the LFSC in 2012 to record and preserve quotidian facets of the London-based diaspora's digital presence, and thus mitigate the inevitable risk of 'heritage lost' (Bingham and Byrne, 2020, p. 4). A central premise of this article is that the LFSC is the product of my culturo-linguistic expertise and identity, as well as my 'cyberfeminist sensibilities' (Laboria, 2015: $0 \times 13$ ). I posit that, together with the multilingual women curators of the UK Web Archive's other translingual diasporic micro-archives (Brügger, 2012), the curators embody difference through their agentive incorporation of languages from 'other' cultures; ${ }^{2}$ and that their curatorial work on minority digital diasporas shakes the patriarchal, neo-colonial hierarchies that tacitly underpin national memory institutions. ${ }^{3}$ By creating these diasporic corpora within the framework of the UK Web Archive, the curators not only deviate from the monolingual anglophone norm dominant in computer studies, internet repositories and the wider web (Fiormonte et al., 2015; Mizumura, 2015; Schroeder and Brügger, 2017; Giannakoulopoulos et al., 2020; Huc-Hepher and Wells, 2021), but they challenge the male tech stereotype and chronic IT gender bias (Pot'Vin-Gorman, 2019). Through their digital curatorial practice, which embeds and memorialises otherness within the Ivory Towers of the British Library, I therefore propose that the women web curators are performing xenofeminist principles (Laboria Cuboniks, 2015; Hester, 2018) and agentively 'recognising the queer potential of web archives' (Ankerson, 2019). ${ }^{4}$

Xenofeminism (XF) is a post-third-wave trans-feminist school of thought created by an international working group known as Laboria Cuboniks. Helen Hester, a founding member of the collective, defines it as 'an attempt to articulate a radical gender politics fit for an era of globality, complexity and technology' (Hester, 2018, p. 7). Curating the LFSC, embodies all three of these strands. It recognises the complexity of community identity and web curation along nebulous 'community' lines (HucHepher, 2015), as well as the central role of digital technologies in cementing migrants' lived transnational experience in an increasingly global world. Xenofeminism, like my own approach to internet curation and analysis, prioritises materiality over information (Hester, 2018; Huc-Hepher, 2015, 2016) and explicitly embraces the 'xenos'-Greek for 'stranger' or 'foreigner'. In this way, it rejects traditional outsider/insider, man/woman, straight/queer binaries perpetuated by previous waves of feminism and by contemporary trans-exclusionary feminists (Phipps, 2020), and foregrounds in-betweenness and openness.

Furthermore, XF associates 'bodily sovereignty' (Hester, 2018, p. 18) with empowerment and sees technical repurposing as a means of performing 21st-century post-third-wave feminist activism. I contend that the inclusion of a diasporic web collection in the UK Web Archive constitutes the active incorporation of these ideals. Questioning the limits of the body and acknowledging its simultaneously material and metaphysical dimensions were ideas explored by leading third-wave feminist thinkers Donna Haraway and Judith Butler, albeit in contrasting cybernetic (Haraway, 1991) and discursive forms (Butler, 1993). Bringing this post-structural corporeal 'queering/querying' (Johnson, 2018) into the 21st century and recognising that 'data has materiality' (Bonacchi and Krzyzanska, 2019, p. 1238, citing Pink et al., 2018), the 'special collection', can itself be conceived of as a tangible corpus, a body of translingual, diasporic material. ${ }^{6}$ In a metaphorical/metaphysical iteration of the transgender body, then, the micro-archive destabilises bi-lingual dualisms and dismantles the linguistic and national borders erected by national archives, which are defined and confined by the limits of their .uk country code Top-Level 
Domain (Webster, 2019). ${ }^{7}$ As Li Wei asserts, the translanguaging practices that typify diasporas, and the LFSC web objects, go 'beyond hybridity' (2018, p. 23) and function instead 'as a Thirdspace' (Li, 2018, p. 24). The LFSC, together with the Latin American, Russian and East and South East Asian (under construction) corpora, thus help to position the UK Web Archive in a progressive thirdspace, transcending binaries and, as such, queering the archive. Indeed, their presence epitomises Michel Foucault's conceptualisation of the archive as a privileged space whose analysis 'shatters the other, and the outside', establishing that 'we are difference' and that this difference 'is this clustering that we are and that we do' (1969, p. 180). By incorporating migrant collections within the UK archival body, therefore, the curators are actively countering the othering discourse of mainstream politics and media, while realising the unifying potential of an inclusive, nonbinary approach to difference.

As established above, I apprehend the UK Web Archive's migrant community Collections as the incarnation of in-betweenness, bridging gender, techno-functional, language and cultural divides, as well as 'blur[ring] former boundaries of authority and authorship' (HucHepher, 2015, p. 7). Moreover, in the case of the LFSC, the corpus embodies 'the multifaceted aspects of this community, from the institutional to the individual, through a variety of genres, discourses and modes' (Huc-Hepher, 2015, p. 2). These include 'macro-level London-French cultural, religious, educational and governmental websites, together with meso-level commercial, philanthropic and local media sites', with the empirical focus of this article being on 'the most personal, micro-level of the collection' (Huc-Hepher and Wells, 2021, p. 192), notably migrant Frenchwomen's blogs. The integration of these multilingual, multimodal, cross-generic Collections in the UK Web Archive resists the implicit hegemonies of a predominantly monolingual (Schroeder and Brügger, 2017), ${ }^{8}$ 'restrictive and conservative online landscape' (Hester, 2018, p. 91), where the (straight) white male perspective is the default setting and data is inherently biased (Criado Perez, 2019; Thompson, 2020). Rather than inducing a mal d'archive (Derrida, 1995), therefore, I posit that this transgenre, translingual and transcultural inbetweenness is in harmony with the underlying principles of the archive and indicative of its contemporary 'wellbeing'.

I argue that diasporic web curation praxis and scholarship foreground the human in the Digital Humanities by giving speech (Sassen, 2013) to a relatively quiet minority community. I accept, however, the 'performative contradiction' and power dynamics at play (Ahmed, 2015) through my articulation of this xenofeminist argument from the privileged position I occupy as a white, European scholar and LGBTQIA + ally, and that the French in London occupy as 'valuable', 'EU migrants' (Lulle et al., 2018, p. 2; Walsh, 2018), economically comfortable enough to devote the requisite time and energy to maintaining a blog presence (Huc-Hepher, 2021) and unrepresentative of the (French) trans community itself. Indeed, it is important to note that while the UK Web Archive contains a dedicated LGBTQ+ Lives Online special collection, together with corpora on Men's Issues and Women's Issues, all of which house trans material and unequivocally queer the archive, neither this article nor the diasporic collections I scrutinise are dedicated to trans bodies or transgender politics in a literal sense. I use the term 'trans', 'trans-inclusive' and 'trans body', etc. throughout this paper as a theoretical construct to reflect the openness to otherness integral to xenofeminism and as a metaphor for the positive in-betweenness that non-anglophone diasporic collections bring, whether linguistically, modally or generically. However, my allusions to the 'trans body' as a conceptual lens in no way seeks to flatten or minimise the very real struggles facing individuals living in physical trans bodies. Nor does my figurative borrowing of the trans prism seek to contest the important queering affordances of the dedicated LGBTQ + collections mentioned above. Rather, by theorising the incorporation of culturally and linguistically diverse diasporic collections as a means to constructively queer the anglo-centric, nationally circumscribed norm, I intend to contribute to contemporary decolonial, (xeno) feminist and non-normative debate by offering a paradigm applicable to other collections, archives and contexts. Equally, I appreciate that my emphasis on London-French women bloggers could be seen to re-assert gender binaries, as opposed to diminishing them (Butler, 1988). Nevertheless, I maintain that such an emphasis does not single out women's voices to the detriment of, or in opposition to, others; rather it acknowledges women within an overarching xenofeminist framework that is necessarily open to other trans-iterations, while going against the patriarchal grain.

Notwithstanding the aforementioned caveats, I am committed to investigating how hosting minority migrant collections in the UK Web Archive performs 'xeno-hospitality' (Hester, 2018, p. 64) and queers the archive through the blurring of gendered/ generic binaries and the embodiment of multiple metaphorically 'trans' identities. Underscoring the overlap between gender and genre, I show how the figure of the trailing wife (Cooke, 2001) is disrupted (Stockdale, 2016) by the dominance of women bloggers in the London-French blogosphere. I also contend that the functional ambiguity of their LFSC web objects subverts the original purpose of the blog genre and that this cognisant repurposing is performed as a techno-materialist act, thereby aligning them with $\mathrm{XF}$ ideologies. Finally, examining two archived London-French blogs over time, I contend that they themselves transform, to become linguistically and culturally ambiguous, embracing the in-betweenness of the bloggers' transnational identity (Parker and Song, 2007) and the inbetweenness of multimodal online translanguaging (Tagg and Lyons, 2021).

Laboria Cuboniks state that 'XF seeks to strategically deploy existing technologies to re-engineer the world' $(2015,0 \times 02)$. The aim of this article is to show how the diasporic community collections in the UK Web Archive are one component in the mechanics of this long-term process.

\section{The archive as a (trans)gendered body}

In 'The Spectacle of the Other', Stuart Hall contends that People of Colour are 'represented through sharply opposed, polarised, binary extremes-good/bad, civilised/primitive, ugly/excessively attractive, repelling-because-different/compelling-because-strange-and-exotic. And they are often required to be both things at the same time!' (1997, p. 229; original emphasis). He explores how mainstream media 'fix' difference through such images and generate otherness through these 'split figures' (Hall, 1997). While the experience of (white) EU migrants is in no way comparable to the endemic structural racism and white supremacist status quo with which People of Colour are routinely confronted, Hall's assertion nevertheless recalls the fixing of difference by populist print, online and social media in relation to EU citizens. Indeed, tabloid journalism's perpetuation of such binary tropes arguably contributed to the UK's departure from the EU in January $2020 .{ }^{9}$ The image of the French person as the ultra-appealing 'sex bomb', intellectually and seductively agile, and simultaneously the ultra-repulsive horsemeatand frog-leg-eating deviant who rarely washes (Huc-Hepher, 2019) is emblematic of this 'split figure'. By including the LFSC in the UK Web Archive and incorporating a diverse range of complex multimodal migrant web objects in the LFSC micro-archive, I assert that, as a malleable and evolving concept-corpus, the archive actively counters such othering. Instead of splitting and fixing difference, it embraces otherness and presents multiple facets of the xenos in their language and in original, unmediated form. Jacques Derrida would doubtless dispute this emphasis on the authentic 
original (1997) and indeed I have myself previously problematised the complexity of originality in web archives (Huc-Hepher, 2015), when an archived capture is only ever one instance of the multiple versions that exist (Brügger, 2012; Milligan, 2019). Yet, the Collection is nevertheless a raw, or at least 'pre-cooked' (Bonacchi and Krzyzanska, 2019, p. 1240, quoting Rieder et al., 2015), portrayal of the community, the websites being harvested and preserved in as much their originary form as technically possible and without any institutional or curatorial reworking beyond their co-presentation in the 'community' corpus.

This co-presentation is an important point, however, since it gestures towards the ambiguity and in-betweenness at the very core of the archive itself. As Derrida asserts, the word 'archive' is intrinsically ambivalent: the Greek arkhé means both commencement and commandment (1995, p. 11), commencement pointing to the original source and commandment to the authority that oversees and houses it. By the same token, commandment implies bringing order to the archived material through an 'archic function, in truth patriarchic' (Derrida, 1995, p. 14). ${ }^{10}$ That is, by co-presenting material in a single archive, the memory institution is exercising authoritarian 'archontic power which also involves processes of unification, identification, classification' and which goes hand in hand with 'the power of consignation' (Derrida, 1995, original emphasis). Here, it is important to clarify that the notion of consigning goes beyond its allocational definition, meaning also to coordinate in a single corpus, in a system or synchrony in which all the elements articulate the unity of an ideal configuration' (Derrida, 1995). As well as entrusting and submitting, therefore, consigning represents togetherness (con) and meaning-making (sign). Through this process of institutional, patriarchal homogenisation, which ultimately seeks to bring order to the messy, heterogenous material by uniting it in a single, unified body, difference is typically negated and additional meaning injected. The inclusion of the LFSC and other community micro-archives in their original languages and discursively diverse forms consequently subverts-or even perverts-the hegemonic anglophone norm. In this sense, the diasporic Collections not only contribute to decolonising the archive (Das and Lowe, 2018), but to queering it.

Derrida contends that the mal d'archive is a sickness borne of the archive's intrinsic incompatible dualities. Replete with contradictions, from its twofold inception as arkhé, the archive's plurality is judged problematic (1995, p. 142), foiling its unifying purpose. These dichotomies are articulated through the web archive in multiple ways. It is both public and private, presenting sometimes personal (hi)stories in a public memory institution on the worldwide-web, both present (visible) and absent (invisible) through its open-access directory and often onsite-access reality. ${ }^{11}$ It is both here and there, past and current (Bonacchi and Krzyzanska, 2019), spanning pre/postmigration spaces and collection/consultation temporalities, as well as incorporating data that is at once on-land and on-line, digitally born and reborn. It is both a 'totality' and 'fragments' (Foucault, 1969, p. 179), 'both close to us, but different from our here-and-now', constituting 'the edge of time which surrounds our present' (Foucault, 1969), yet situated between 'tradition and oblivion', and between 'langue' and 'corpus' (Foucault, 1969, p. 178; original emphasis). It is, as Derrida postulates, creative through a fear of destruction, generative of knowledge through acknowledgment and protective of the future through preservation of the past, in what Hanchao Lu has fittingly termed 'nostalgia for the future' (quoted in Farrer, 2010, p. 1214). It is these binary tensions, this essential irreconcilability that, according to Derrida, results in the archive's malaise. The mal d'archive is not just a sickness triggered by the sense of mal du pays or homesickness inherent in the archive and prompted by the aching yearning to return to the origin(al), 'to the most archaic site of the absolute beginning' (Derrida, 1995, p. 142), akin to the longing integral to belonging among migrants (Yuval-Davis 2006; Levin, 2016), it is also a sickness caused by its 'internal division', its 'two contradictory forms' (Derrida, 1995, p. 142, 140).

For Derrida, inspired by Freud, the archive's fundamentally trans identity is its 'trouble' (1995, p. 141). This both recalls and rebuffs the Gender Trouble (1990) evoked by Butler and revisited, terminologically if not conceptually, by Haraway (Staying with Trouble, 2016) and Alison Phipps (The trouble with mainstream feminism, 2020). Whereas Butler, Haraway and Phipps call into question the notion of stable gender binaries, Derrida holds the singular embodiment of duality responsible for the archive's ills. $\mathrm{He}$ (fittingly) plays on the double-entendre of 'trouble' in French to do so, alluding to its concurrent troubling and blurring capacity. Thus, for Derrida, the embodied fusion of binaries is deemed the archive's problem, its Freudian disorder. But an XF reading of the archive would, on the contrary, consider this singular embodiment of dichotomies to be its making, something to be acknowledged, embraced, celebrated even. As Laboria Cuboniks write in their manifesto, the 'malady of melancholia only compounds political inertia... [and] relinquishes all hope of calibrating the world otherwise. It is against such maladies that XF innoculates' $(2015,0 \times 09)$. In rejecting the construction of the archive as a nauseating in-between figure and instead apprehending it as an autonomous trans body, it is transformed from the incarnation of malaise to that of Pride, the unapologetic affirmation of intersectionality 'that slices through every particular, refusing the crass pigeon-holing of bodies' (2015, 0x0F).

The word 'gender' is derived from the French 'genre' and there is again an intrinsic dualism here. If the archive is a corpus that mixes genres (Huc-Hepher, 2015), etymologically it is also a body that combines genders and is thus innately queer and productively intersectional. It is this transcending of generic and gender binaries that befits a theoretically queer approach. Lee Edelman argues that 'queerness can never define an identity; it can only ever disturb one' $(2004$, p. 17) and if we return to the notion of archiving as a form of consignment, with an emphasis on the 'con-sign', the LFSC micro-archive can be interpreted as a coproductive means of disturbing the identity of the UK Web Archive, but not redefining it-at least not entirely and not in isolation. It remains a UK-based web archive where English dominates, but one which is being queered by the presence of difference. Queerness 'acquires its meaning from its oppositional relation to the norm... [and] is at odds with the normal, the legitimate, the dominant' (Halperin, 1995, p. 62). In this sense, as a collective that both stands apart from and within the prestigious national repository, it is the combination of minority community micro-archives that begins to undermine the heteronormative 'patriarchive'. Indeed, in recognising that the 'universal must be grasped as generic', as Laboria Cuboniks assert (2015, 0x0F), the gendered/generic queering of the UK Web Archive tends towards a post-third-wave redefinition of its universality. The French, Russian, Spanish and forthcoming East and South East Asian webpages that now inhabit [the UKWA,] this peculiar place, this place of [s]election where law and singularity intersect in privilege' (Derrida, 1995, p. 13), together create a form of queer 'domiciliation' (Derrida, 1995, p. 14), where difference begins to reinvent the norm and post-third-wave 'xeno' feminist principles repurpose trans-exclusionary feminist ideologies.

By curating the East and South East Asian, Latin American, London French and Russian micro-archives, the multilingual women curators are actively questioning the role of power in saving... the past, particularly when exploring gender, marginal groups, and the everyday experiences of ordinary users' (Ankerson, 2011, p. 388; Parker and Song, 2007). Meanwhile, by providing a space for websites created in 'other' languages and, in 
the case of the LFSC, an assemblage of London-French blogs which are almost exclusively created by women, the UK Web Archive is effectively ' $[w]$ riting against institutional histories that tend to privilege the sphere of men..., trying to recover marginal histories that escape the archive' (Ankerson, 2011, p. 389; Ogden et al., 2017; Bingham and Byrne, 2020). In so doing, the genre/ gender distinctions that typically define and territorialise archives begin to be dismantled. Equally, by crossing the invisible boundaries (Abutbul-Selinger, 2018) of language, culture and nation-state in its provision of a shelter (Derrida, 1995) for the cultural heritage of digital, transnational diasporas, the UK Web Archive is constructively transgressing the contested territories described by Haraway (1991).

The UKWA's domiciliation of diasporic East and South East Asian, French, Latin American and Russian digital spatialities and temporalities therefore disrupts hegemonic patriarchal and postcolonial structures (Rao, 2020). As Roland Barthes argued in relation to photography, the snapshot of an archived website provides the onlooker with a haunting image suspended between a dead past and a living present (1980). Its very 'immobility ... is like the result of a perverse confusion between two concepts: Real and Alive' (1980, p. 123). But in the case of captures of migrant websites, these 'perversely' ambiguous temporalities are complicated further, often presenting the here of their present and the there of their past, subsequently transposed into the then of the archived website instance and the now of the archive user's interaction. Moreover, beyond these temporal confusions and transgressions, the UKWA's incorporation of diverse migrant digital spaces could be seen to reflect 'the tension between diasporic pluralism and territorial stability in the project of the modern nation-state' (Appadurai, 2019, p. 560). Nevertheless, I would argue that rather than embodying a 'tension', which echoes Derrida's mal d'archive (1995), this inclusion confirms 'the limitations of the ccTLD [country code Top Level Domain] as a proxy for the national web' (Webster, 2019, p. 110; my italics) and establishes the national archival cyberspace as an increasingly pluralistic, multilingual, multicultural and intrinsically queer body. In the footsteps of Haraway, therefore, this article is an argument for pleasure in the confusion of boundaries and for responsibility in their construction' (1991, p. 151).

\section{Blog repurposing as a xenofeminist act}

Some of the most socio-culturally, linguistically and empirically rich data in the LFSC are found in blogs. This section therefore goes one step deeper into the archive to examine the blog genre/ gender through the prism of xenofeminism. Having problematised the dualism at the heart of the archival word and form, I now explore how this trans identity is figuratively applicable to London-French blogs. Being a portmanteau of 'web' and 'log', the 'blog' simultaneously embodies the public dimension of the World Wide Web and the privacy of the personal diary or 'log' (Huc-Hepher, 2015). It provides an openly accessible, material trace of the migrants' 'intimate subjectivities across and through dialectics of mobility and settlement' (Walsh, 2018, p. 146) and is once again, therefore, the product of inbetweenness. In this sense, the London-French blog epitomises the extimité (exposed intimacy) concept proposed by Serge Tisseron (2001), together with that of online migrant narrative as a 'living archive' of their transnational trajectory (Appadurai, 2019, p. 561). This framing of digital diasporic expression as a living log, where 'confusion [over loss and memory] often leads to a deliberate effort to construct a variety of archives, ranging from the most intimate and personal (such as the memory of one's earlier bodily self) to the most public and collective, which usually take the form of shared narratives and practices' (Appadurai,
2019 , p. 562) is crucial, as it takes us back to the physicality of the archive, to the subject-object blending alluded to by Butler $(1990,1993)$ and ultimately to the blog as genre, gender and body.

It is significant that the 19 open-access blogs housed in the LFSC are all, by chance rather than curatorial design, the creations of women bloggers, and many other web objects in the Collection also belong to French women migrants, including the Regards de femmes (www.regardsdefemmeslondres.org) conference site run by nine women, the Ici Londres community magazine site (www.ici-londres.com) led by a team of women journalists, editors and administrators, together with individual websites connected to French women's commercial activity in London, such as the psychologist responsible for Marie's Counselling (www.mariescounselling.com) and the site dedicated to the visual artist, Eléonore Pironneau (www.eleonorepironneau.com). These web objects are an online materialisation of the migrants' everyday on-land lived experience and, as such, they embody the dynamic in-between space of the bloggers' contemporary digital-physical existence. This is what Christine Hine refers to as 'the embodied Internet' (2015, p. 14) and, in an inversion of the idea, which underlines the dynamics at play, what Mark Hansen describes as 'bodies in code' (Hansen, 2007). The distinction between blog and blogger is hence ever hazier and has led to the advent of a materialdigital, subject-object body (Asenbaum, 2019), whereby, instead of 'being a transcendent cyberspatial site of experience, the Internet has increasingly become part of us' (Hine, 2015, p. 14). In addition, the collection, or consignment, of blogs within a single archival corpus allows them to take on an identity as a community body. In keeping with Appadurai's contention that common narratives and practices create a collective living archive (2019), we observe how the London-French blogosphere-which is networked both on-line and on-land-has 'enabled individual bodies to become attached to and emboldened by entities greater than themselves' (Shilling, 2016, p. 6; Huc-Hepher and Wells, 2021; Tagg and Lyons, 2021), in this case, a diasporic blogging community. Similarly, since 'online audiences are the imaginings of the poster's understanding of a community's practices' (Tagg and Seargeant, 2014, p. 181), the London-French generically connected blog-body is engendered by a dynamic between the individual and the collective.

When Haraway wrote her seminal manifesto in 1985, she predicted the boundary-blurring potential of mechanised technology: 'we are all chimeras, theorised, and fabricated hybrids of machine and organism; in short, we are cyborgs' (1991, p. 150). Pertinently, she extended the cyborg metaphor to 'post-gender' binary-breaking. It is unlikely, however, that she foresaw this transfiguration being enacted so vividly within only a generation or that women would be harnessing this 'technomaterialist' energy (Hester, 2018) to such an extent that Myspace sites have been termed digital bodies (Boyd, 2008) and girls' blogs, avatars representing 'both the body and the spirit' (Vaisman, 2016, p. 307), hence recalling the 'embodied avatars' problematised by Uri McMillan (2015). This new digital materialism (Asenbaum, 2019), which recognises that '[d]igital technologies are not separable from the material realities that underwrite them' (Laboria Cuboniks, 2015, 0×13), has seen the emergence of 'hyperbodies' and 'digibodies' (Flanagan, 2002, 2013), 'performative thingly data-bodies' (Thompson, 2020, p. 3) and even 'cyborg witches' (Thorburn, 2017, p. 153; Hester, 2018, p. 142). Today, as Hester indicates, the second-wave-feminist witch figure, herself the ancestral embodiment of suppressed intellect and skill, has been 'upgraded for the twenty-first century via hybridisation with a wider range of technological devices' (Hester, 2018, p. 142), including the internet. The cyborg witch, self-proclaimed by the post-capitalist, post-third-wave-feminist Catalan collective, GynePunk, thus extends to 'embodiment and gender itself (Hester, 2018, 
p. 143). And this quest to agentively decolonise the female body has given birth to 'a technologically literate, (re)purposeful feminism' (Hester, 2018). As Thorburn maintains, the blog/witch 'cyborg is then a way of thinking solidarity-and composition-in transnational, intersectional terms, within and through conditions of twenty-first century techno-capitalism' (2017, p. 160).

While I do not claim the women bloggers in the LFSC to be engaged in the same type of feminist activism as the DIY GynePunk group, I argue that their appropriation of digital tech to tell their migrant stories and, further, to remodel the intended function of the blog genre is a technomaterialist act that corresponds to 'xenofeminism's gender abolitionist approach' (Hester, 2018, p. 143). GynePunk are an extreme group of TransHackFeminists who live off-grid, literally and metaphorically on the margins of 'society' in a post-industrial 'no-man's-land' outside Barcelona. The French women bloggers in my micro-archive could, for the most part, not be more different. They appear to be a white, middle-classed category of privileged migrant (Walsh, 2018, p. 7), many of whom inhabit the leafy suburbs of West London or the 'hip' cultural hub in the edgier East End (Huc-Hepher, 2021), but none seems to be living an 'alternative' lifestyle and their migration to London was likely a choice rather than a necessity. However, the women's creative use of publicly available digital technology and shrewd repurposing of their blogs confirm the (post-)third-wave feminist affirmation that 'technology is not inherently male and can serve women equally well' (Skowronsk, 2015, p. 27). The predominance of women's blogs in the micro-archive is testament to both the dominance of women migrating from France to the UK in the nineties and noughties and to the fact that they 'find [the tech] empowering', rejecting the idea that it 'violates their true feminine nature' (Skowronsk, 2015; Pitman, 2018).

On the contrary, I have discussed how blogs serve as extensions of the bloggers' bodies, such that the London-French corpus functions as 'a hypomnesic or technical archive, a (material or virtual) prop or subjectile', where the blog-body morphs into a 'technical prosthesis for secondary and ancillary exteriority' (Derrida, 1995, p. 143; Ogden et al., 2017, p. 299). Thus, by using their blogs strategically, not simply as personal diaries but as commercial tools for related businesses (e.g. in graphic design, travel or photography) or as a source of income in their own right (e.g. through advertising agreements), the women bloggers disrupt the genre of the blog and the tech patri-archetype. In this way, the blogs function as 'synthetic genders'/genres (Hester, 2015; Laboria Cuboniks, 2015), the queering potential of which counters the negative framing such commercialisation often elicits (Parker and Song, 2007). They are 'more-than-human' (Thompson, 2020, p. 2), queered 'digibodies' (Flanagan, 2013), whose 'posthumanist' (Hester, 2019, p. 70) trans-feminist artificiality emerges as an anthropo-plastic 'locus of emancipatory endeavour' (Hester, 2018, p. 137). ${ }^{12}$

In the LFSC, therefore, we observe the (trans)gendering of the blog genre through its embodiment at the interface of digital and material form, and a technomaterialist articulation of women's authorship/authority (Huc-Hepher, 2015). The reconditioned blog is effectively a site for both the performativity and destabilising of genre/gender, whereby the women migrants agentively produce a blog-body which is an extension of selfhood, not 'merely factic materiality; it is fundamentally dramatic ... the body is not merely matter but a continual and incessant materialising of possibilities' (Butler, 1988, p. 521). Moreover, this inventive technomaterialist queering of the blog form by selfaffirming women migrants mirrors what could be apprehended as feminist mobility practices identified on-land. According to French Consulate figures, there were 20,002 French women registered as residents in 1992, against only 9956 men. Ten years' later, that figure had increased to 37,475 and 22,610 respectively, reaching 39,826 against 24,216 in 2003 (Bellion, 2005, p. 8). French women migrants therefore not only outweighed their male counterparts, but did so strikingly at the dawn of postMaastricht intra-EU migration. ${ }^{13}$ This is testament to the women's agency, as well as to their spirit of adventure and enterprise, which turns the traditional notion of the 'trailing wife' on its head (Stockdale, 2016).

Migration thus emerges as a feminist act in itself, a performative mechanism for women to enact their independence by leaving behind the sexisme ordinaire (de Beauvoir, 1979) encountered in France, in search of the liberating anonymity offered by London as an open, global, multicultural and multilingual city (Huc-Hepher, 2021). As Jon Mulholland and Louise Ryan ascertain, French women migrants find 'freedom from the normative judgement of others' (2017, p. 143) through their mobility to London, 'defined as a place where a woman could enjoy autonomy' (Mulholland and Ryan, 2017). The possibility for a performative reinvention of self in London resonates with the quest for embodied empowerment among other women migrants, notably mainland Chinese women living in postcolonial Hong Kong (Wang, 2013), despite the incontestable differences in each group's lived experience both pre- and post-migration. In this way, the migrants contribute to a wider process of autonomous gendered mobility at the turn of the 21st century but, in the case of London-French women bloggers, this mobility-driven 'resubjectification' (Conradson and Latham, 2007, p. 234) goes further. Its materialisation and digital embodiment in the queered blog genre confirm the women's enactment of 'positive freedomfreedom-to rather than simply freedom-from' (Laboria Cuboniks, 2015, 0 $\times 07)$. As established in the XF manifesto, 'more than digital self-defence and freedom from patriarchal networks' (Laboria Cuboniks, 2015), their blogging is a productive and creative articulation of their autonomy, whereby the 'women ... apprehend and narrate their individual and collective digitally mediated heritages' (Thompson, 2020) on their own terms, underscoring their positioning as assertive and successful migrants in the London space and in the UK Web Archive.

Ankerson writes that 'we should be acutely aware that absences shape histories as much as artifacts' (2011, p. 398). By giving these grassroots' London-French women's web objects a presence in the LFSC micro-archive and ensuring a bottom-up 'making of presence' (Sassen, 2013, p. 221) through the UKWA's public 'nominate-a-site' crowdsourcing function, I have demonstrated an awareness of their importance in the diasporic (hi)storymaking of the archive, as well as exercising 'a feminism sensitive to the insidious return of old power structures, yet [been] savvy enough to know how to exploit the potential' (Laboria Cuboniks, 2015, $0 \times 13$ ). Furthermore, by shedding light on the transgenerative power of French women's blogging, I have, as prescribed by Haraway (1991), met my 'response-ability' (Haraway, 2016 , p. 2) to actively contribute to the deconstruction of heteronormative boundaries. Indeed, the progressive incorporation of multilingual diasporic user-generated content in the predominantly monolingual, national web archive serves as 'a profound challenge to political whiteness' (Phipps, 2020, p. 164) and straightness, for, as Phipps asserts, 'binary gender ... is inextricably bound up with racial capitalism' (2020, pp. 164-165; Haraway, 1984), to which anglophone exceptionalism can be added. It is 'a colonial and capitalist project', where 'borders of class and nationality are at one with the borders of gender' and crossing them is perceived as a threat to 'the colonial mindset' (Phipps, 2020, p. 156). Such attitudes have been sedimented through centuries of white supremacist (re)production, as Moira Inghilleri attests when alluding to 17th-century North American colonists' refusal to learn any of the local languages, deemed uncivilised and menacing (Inghilleri, 2016). Moreover, to adopt 
the tongue of another requires empathy, receptiveness and the physical incorporation of the xenos, none of which is compatible with the imperial paradigm. Thus, through my 'productive, rather than vindictive' (Phipps, 2020, p. 169) dismantling of spatiotemporal, generic/gendered, national and linguistic borders in the UK Web Archive, I have made a progressive, transactivist contribution to the development of a new institutional universality, one which is simultaneously translingual, transcultural and transgenre. In the next and final section, through the prism of multimodality, I analyse the queering affordances of the archived blogs themselves.

\section{The queering of language and culture in archived blogs}

In this section, I take a final step deeper into the archive to focus on the substance of the archived material itself. Consistent with Halperin's definition of queerness mentioned previously, that is, acquiring 'meaning from its oppositional relation to the norm' (1995, p. 62), I purposefully 'read against the grain of algorithmic logics of probability and prediction' (Ankerson, 2019). In considering the semiotic potential afforded by the fleshy materiality of London-French blogs (Ankerson, 2019) and the meaninggenerative capacity of the languaging practices and in-between space of the modes within them (Kress, 2010), my XF analysis aims to disrupt the norm of deterministic digital positivism (Fuchs, 2017; Thompson, 2020), itself an extension of racial and gendered capitalism (Phipps, 2020). This section distances itself from the 'style over substance' debate and apprehends style as substance (Asenbaum, 2019), considering blogs 'as objects [or bodies] to look at rather than to look through for their meaning' (2011, p. 179). In particular, it examines how London-French blogs embody queering transmodal and 'translanguaging' ( $\mathrm{Li}$, 2011, 2018) practices and how, over time, they emerge as increasingly transnational, transcultural 'semiotic assemblages' (Kusters, 2021), blurring national and cultural frontiers as opposed to underscoring them. Moreover, the very means through which I analyse the material, notably through the ethnosemiotic prism of multimodality, is, I postulate, an incorporation of disciplinary and methodological transgression and xenofeminist queering.

Daniel Miller-somewhat provocatively-asserts that '[n]ot establishing a discipline doesn't mean that a study of stuff lacks substance or consequence', rather 'it seeks to welcome this aberration; to embrace the openness and collegiality of not having to be overly disciplined' $(2010$, p. 2). Similarly, in this section I interrogate how the crossing of disciplinary borders results in a fertile trans territory that allows complementary methods and sensibilities to be harnessed progressively. I have provided a detailed account of my 'ethnosemiotic' analytical lens elsewhere (Huc-Hepher, 2015, 2016). My purpose here, therefore, is to set out how this lens characterises XF principles in theory and how it contributes to a queering of the archive in practice. Following on from John Fiske's early and isolated reflections on '[e]thnosemiotics' (1990, p. 85), Phillip Vannini is one of the first scholars to develop a concrete ethnosemiotic framework, coined 'sociosemiotic ethnography' (2007, p. 122). Vannini compellingly prepares the ground for a mutually constructive transdisciplinary approach that merges post-structural semiotics, ethnography and cultural studies. He reminds readers that the trouble with Saussure-inspired positivist structural semiotics is that it is founded on intrinsically hegemonic binaries: langue/parole, synchrony/diachrony, signifiers/signifieds, etc. (Vannini, 2007, p. 120). Such objectivised binaries are necessarily at odds with the subjective 'interactionist' (2007, p. 123) methods and fluid humanistic sensitivities of ethnographers and social semioticians. They flatten the three-dimensional polyvocality of lived experience and compress it into two-dimensional essentialist categories; whereas 'sociosemiotic ethnographers must be prepared to embrace a multidimensional approach' (2007, p. 122), recognising discourses and texts, experiences, and social, historical, and geo-political circumstances' (Vannini, 2007).

Gunther Kress (2011) takes the idea further, underlining the complementarity of multimodal social semiotics and ethnography. Kress "recognises the "reach" of each of the two approaches and turns away from an "imperialist" attitude which might insist that "everything can be done with this [particular] theory and its methodology"' (2011, pp. 245-246). In so doing he gestures towards a potential epistemological and ontological 'merger, a "unification" of frameworks and methods' (2011, p. 241), which is consistent with the universal trans body and the position that (social) '[s]cience is not an expression, but a suspension of gender' (Laboria Cuboniks, 2015, 0×04). My ethnosemiotic prism, therefore, 'marks the point where these [disciplinary] claims intersect in a two-way dependency' (Laboria Cuboniks, 2015) rather than in a severed dichotomy. That is, in 'becoming "critical friends" (Ames and Lewis, 2020, p. 4), the ethnographic and the semiotic productively embrace 'porous boundaries ... and the crumbling of silos' (Ames and Lewis, 2020, p. 5) to deliver a new, transdisciplinary whole.

Magnifying the lens yet more, we see that the multimodal analytical toolkit (Jewitt, 2011) deployed for the ethnosemiotic examination of online resources is itself inherently inclusive. Central to its XF identity is

the assertion that 'language' is just one among the resources for making meaning; and that all such resources available in one social group and its cultures at a particular moment ought to be considered as constituting one coherent domain, an integral field of nevertheless distinct resources for making meaning; all equal, potentially, in their capacity to contribute meaning to a complex semiotic entity' (Kress, 2011, p. 242; my italics).

Instead of awarding primacy to the written word, to a particular language or to the visual medium, as in the case of analytics associated with discrete (sub)disciplines such as linguistics, discourse analysis, art history or photography, multimodality embraces numerous meaning-making modes within a singular semiotic orchestration in a way that, metaphorically speaking, could be likened to the pluralistic embodiment of gender in an individual trans or queer body. Furthermore, it actively recognises the meaningfulness of the in-between space connecting different modes (Kress, 2010) and the semiotic affordances pertaining to intersections within the same mode (Ravelli and van Leeuwen, 2018). This modal equality and interchangeability recalls and performs 'xenofeminism's universalist ambitions [and] comprehends itself as a mobile and intricate network of transits' (Laboria Cuboniks, 2015, $0 \times 17$ ). It rejects the idea that '[c]ulture itself is binary' (Miller, 2010, p. 8) and, on the contrary, aims to invite contamination as a mutational driver between such frontiers' (Laboria Cuboniks, 2015, 0×17). We note, therefore, the disruptive potential of ethnosemiotic and multimodal approaches, as well as their affinity with trans-inclusive XF ideologies. It remains to be seen how this multimodal lens, trans-modal even, reveals a comparable fusing of language and culture when applied to specific archived blogs and, by the same token, how it serves to queer the anglo-centric, nationally circumscribed UK Web Archive.

In their XF manifesto, Laboria Cuboniks assert that 'the task of engineering [online] platforms ... cannot ignore the cultural and semiotic mutations these platforms afford' (2015, 0x0D). Relying on the historical monitoring that web archives permit, I now turn towards precisely such mutations. The archive's collection of 
snapshots of the 'same' blog over time means that even subtle multimodal changes are recorded, preserved and consultable. Concentrating on the Lost (and Found) in London Figs. 1, 3, 4 and 6) and the Londres Calling (Figs. 2 and 5) blogs, considerable semiotic reinventions are identifiable over a relatively short period, from 2010 to 2012. Alongside these noticeable visual redesigns are less discernible examples of diasporic translanguaging. We see clearly how the blog embodies the transnational positioning and identity of the blogger through its rich, located and mutable linguistic repertoire. Crucially, we also discover how such translanguaging takes us beyond the realm of hybridity to an inherently trans idiom that makes its meaning through the embracing of other modes in the digital semiotic orchestration. Given that 'there is in principle equity between all modes' (Jewitt, 2011 , p. 13), the idea of 'code switching' between two languages or giving precedence to written language over spoken language (or vice versa) is retrograde $(\mathrm{Li}, 2018)$ and arguably transexclusionary in the allegorical sense applied here. Likewise, the 'trouble' with hybridity is that its very construction tends to depend on a binary, whereas the purpose of this paper and XF more generally is to cut across such dualisms. Indeed, 'XF seizes alienation as an impetus to generate [...and] mutates, navigates and probes every horizon' (Laboria Cuboniks, 2015, $0 \times 01$ ). Thus, when Li Wei writes that ' $\mathrm{t}$ ] ranslanguaging embraces the multimodal social semiotic view that linguistic signs are part of a wider repertoire of modal resources that sign makers [... deploy to] perform their different subjectivities' (2018, p. 22), we understand why it is apprehended 'as a Thirdspace which does not merely encompass a mixture or hybridity of first and second languages' (Li, 2018, p. 24) but transcends language per se (Kusters, 2021).

There are myriad examples of this multimodal queering in the London-French blogosphere (Huc-Hepher, 2016, 2021; HucHepher and Wells, 2021) and in the two blogs selected for analysis below. Significantly, it is notable that the bloggers have not chosen to create two distinct versions of the blogs, one in French and one English (often symbolised by a French or UK flag, whose erroneous conflation of language with nationality only compounds divisions), but they have produced a single blog entity that transits between French and English, typically within the same phrase or meaning-making segment of text. In the earliest instance of the Lost (and Found) in London blog (Fig. 1), captured in 2010, we observe that the blog name is in English, but the navigation menu tabs are in French: 'Page d'accueil' (Welcome page) and 'A propos' (About). However, the rest of the page is firmly embedded in the French language and culture. From the formal post title, 'La devinette du mercredi \#14' to the cryptic wording of the post itself 'je vous propose un «Cékidonc»', French wording dominates.

Beyond the language, however, the very idea of a 'Wednesday Guess-Who Game \#14' positions the blogpost in a FrancoFrench context, one that is a remembered, absent 'there', despite being (re)presented in the present 'hereness' of the blog/London space. It also recalls the spatiotemporality of childhood, for, as readers familiar with institutionalised French rituals will know, Wednesdays are half-days in French schools and, as such, the mercredi afternoon provides scope for recreational gameplaying. Likewise, the use of the 'Cékidonc' term-a phonetic (mis)spelling of 'c'est qui donc' derived from SMS shorthand, and denoting 'So who is it' in English-again situates the blog in a Franco-French context and suggests the target readership are also located in, or are intimately familiar with, such customs and codes (Tagg and Seargeant, 2014). Even the typography could be considered a mode with equivalent meaning-making potential, given the culture-specificity and intrinsic Frenchness of the punctuation marks (\# and "»). This capture therefore confirms Vaisman's contention that 'practices with orthography and typography demonstrate how people convey social [and cultural] meaning through form and not solely content' (2011, p. 179). Here, the ethnographic meaning inferred from the blog's textual semiotic offer is that the blogger's cultural transformation, or mobility-driven resubjectification, has not yet begun in earnest.

In this 2010 snapshot, the blogger's linguistic and typographical practices position the blog-body in a premigration space and mindset, or primary habitus (Bourdieu, [1972]2000). When analysing the blogpost from a trans-modal perspective, this situatedness is reinforced. Although the image chosen for the banner locates the blog in an in-between space through its depiction of London framed by French words, it is nevertheless a stereotypical photographic representation of the city, its identity

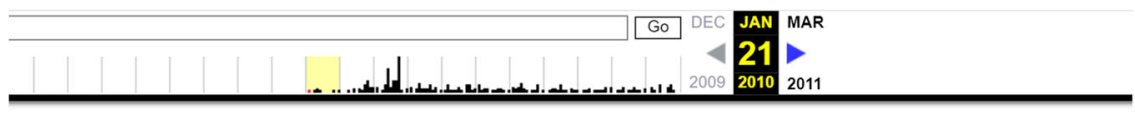

\section{Lost \& Found in London}

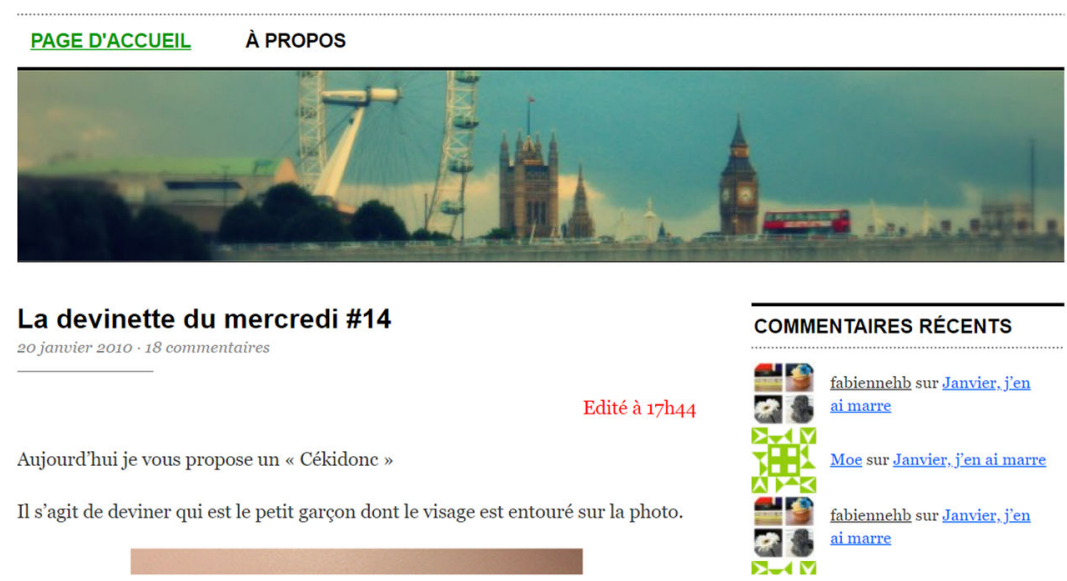

Fig. 1 Lost in London homepage, first capture, archived on 21 January 2010. The original banner conforms to a stereotypical representation of London and the French language dominates. This figure is not covered by the Creative Commons Attribution 4.0 International License. Reproduced with permission of Fabienne Henry; copyright (CFabienne Henry, all rights reserved. 


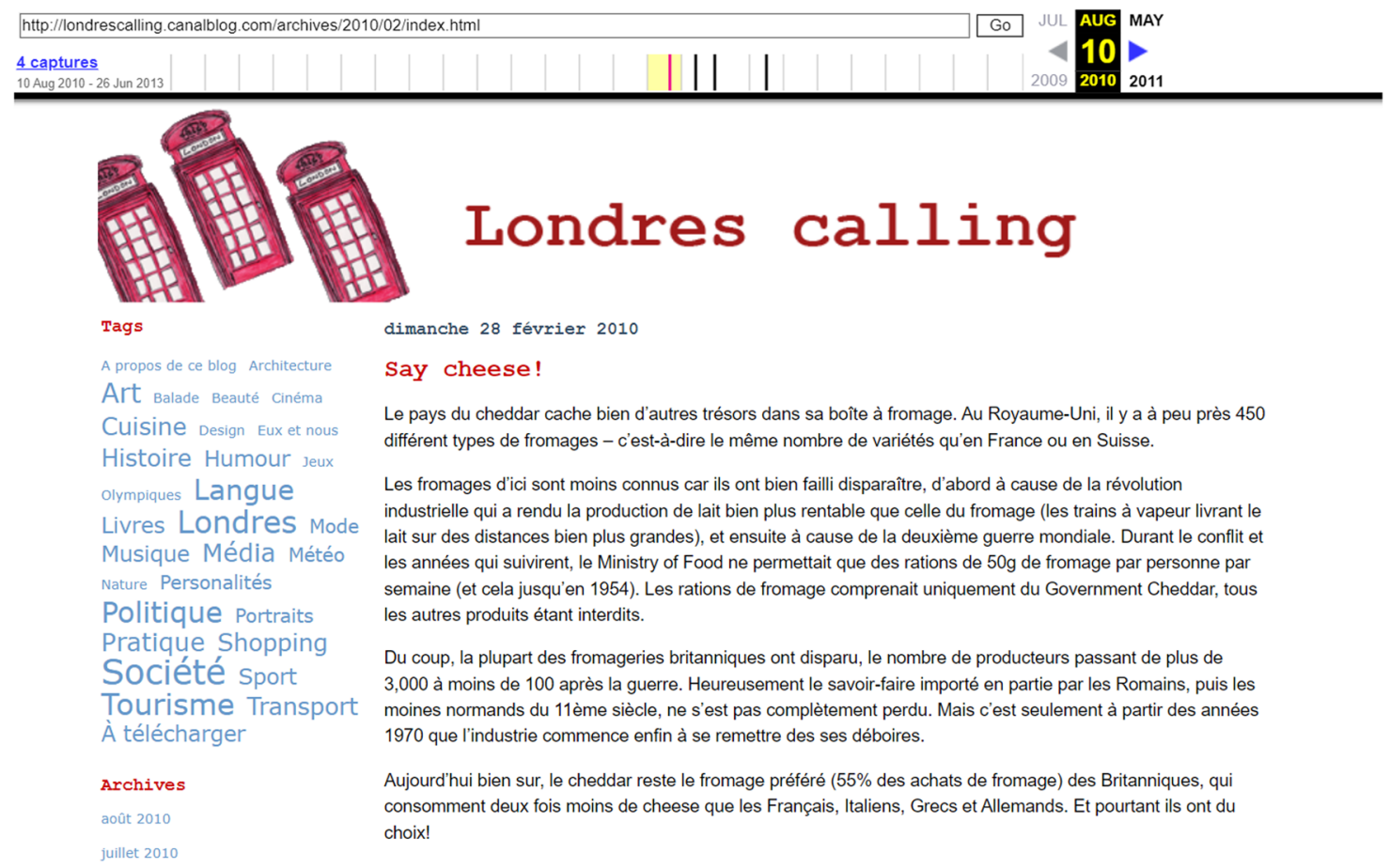

Fig. 2 Londres Calling landing page, archived 10 August 2010. The telephone-booth iconography of the banner again presents London stereotypically, but the language is semiotically more complex. This figure is not covered by the Creative Commons Attribution 4.0 International License. Reproduced with permission of Léa Teuscher; copyright (Clondrescalling.blog, all rights reserved.

depicted through iconic London landmarks: 'Big Ben', the 'London Eye' and a red 'double-decker'. The 2010 capture of the Londres Calling blog (Fig. 2) is equally rooted in the premigration context.

The language is almost exclusively in French, despite some playful-and thus contrived or 'motivated' (Kress, 2010, p. 179) translanguaging in the blog name and blogpost title: 'Londres Calling' and 'Say cheese' respectively. 'Londres Calling' is a complex trans entity. Playing on the (in)famous song 'London Calling' by British punk band, The Clash, it is evocative of the popular youth culture that so appeals to French youngsters and informs their premigration imaginings of the city (which is why Camden Town is placed so squarely on the French tourist-trail). As Bruno, one of my on-land interviewees declared-enacting the 'ethno' in the 'ethnosemiotic' approach-it was 'English music, pop etcetera, British culture, the image it represents in France, the "bobbies", the Union Jack flag ... the cooler, in inverted commas, side than in France' that initially attracted him to London. ${ }^{14}$ Confirming the pull of the mythologised subversive British punk figure, Chantal, another interviewee, described 'this freedom here; it's true, you see punks, people with blue hair, you can wear short dresses and Doc Martens and then dress completely differently six months' later and there's no problem. In France, that doesn't really happen, people are judged a lot on their appearance'. But beyond this 'cool Britannia' (Favell, 2008, p. 177) connotation of the blog name, 'Londres Calling' also speaks of radio transmissions to Europe during the Second World War, each BBC broadcast beginning with the now legendary words, 'London Calling' (BBC, 2005) or, in the case of broadcasts from leader of the Free French Forces, Général de Gaulle, to Resistance listeners in France: 'Ici Londres'. Consequently, the blog title merges both languages, both broadcasts and both historical-cultural references. Moreover, in its present incarnation, it embodies the blogger's relationship to her blog visitors: symbolically, she is the 'Free French' Londoner communicating with her compatriots left behind.
In this way, through the blog name alone, we note a creative crossing of spatial, temporal, national, cultural and language frontiers. However, at this point in time, that is, early in both bloggers' migration journeys, the English words used are those that already inhabit the Franco-French collective consciousness. Like the images that support them trans-modally-whether the London buses or mythical Gilbert Scott K2 telephone booths, compounding the Londres Calling signification-this interlingual practice is, to a certain extent, manufactured. 'Say cheese', for example, is commonly used by French families in the same photograph-posing manner as in anglophone contexts, irrespective of any prior personal or professional connections with the UK. In these early stages of the bloggers' mobility and/or settlement, therefore, the translanguaging is less intricate, less spontaneous and less revealing of a transmuted London-French identity than in later archived versions of the blog-bodies. On the other hand, the prevalence of French underlines the blogs' queering capacity within the anglophone context of the overarching web archive.

Moving forward in time to the 2011 capture of the 'same' Lost in London blog (Fig. 3), the banner has now transformed from the touristic 'presence sheet' (Barthes, 1980, p. 142) to a more culturally complex semiotic whole. ${ }^{15}$ In addition to the background map of London, situating the blog(ger) geographically, the Chubb key is also profoundly characteristic of quotidian life in the British capital. Jeremiah Chubb patented the detector lock in 1818 and the keys remain an integral component of many Londoners' material, on-land lived experience, an element of their 'fractal habitus' (Rowsell, 2011, p. 333). The corner of the TFL Oyster card edging into the frame is semiotically comparable, reminding the blog visitor of the everyday logistics of London residency, accentuated trans-modally by the blog's growing navigation menu, which now includes: 'Carnet d'adresses' (Address book), 'Londres mode d'emploi' (London instruction manual) and 'Que faire à Londres' (What to do in London) tabs. Although this increased geographical scope and embeddedness- 


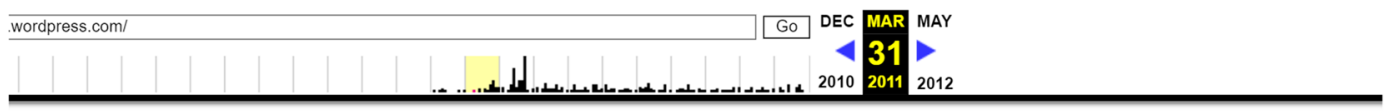

\section{Lost in London}

A vous Londres: pépites, adresses, découvertes et autres trésors.

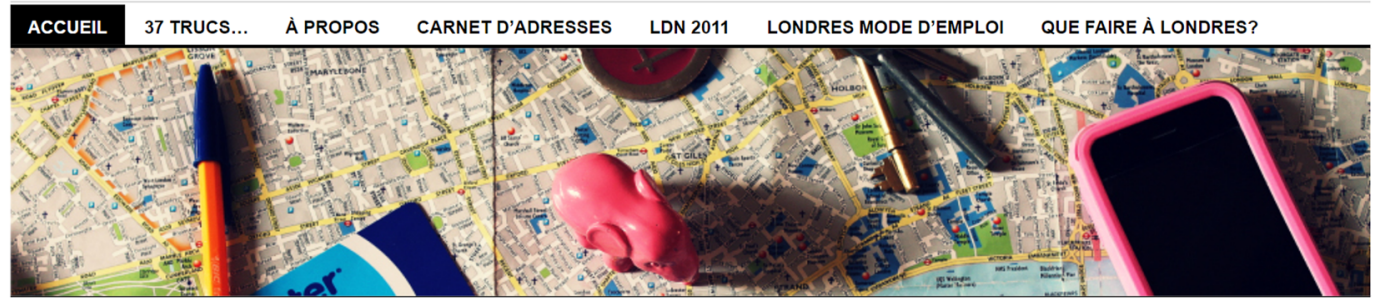

\section{Royale dérive}

Publié le 31 mars 2011 | Laisser un commentaire

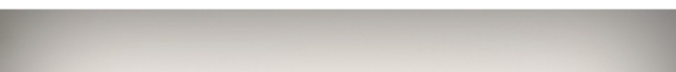

\section{MOLESKINE}

\$. Que faire à Londres en 2011?

\& Prochain Apéro-blog le 13 avrì

$\approx$ NEW - Londres mode d'emploi

\& Nroch - Londres mode d'emploi

Fig. 3 Lost in London homepage, archived 31 March 2011. The photograph in the banner is culturally and semiotically more nuanced than in the original version of the blog, and there is greater modal interplay between the image and the text. This figure is not covered by the Creative Commons Attribution 4.0 International License. Reproduced with permission of Fabienne Henry; copyright (CFabienne Henry, all rights reserved.

textual and visual-bears witness to the blurring of the blogger's on-land/on-line ontological state, the ballpoint pen transports the onlooker back to the French space. While the English word 'biro' is testament to the pen's original inventor, (the Hungarian-born journalist, László Biró, who later migrated to Argentina and the USA, together with his pen), it is the adapted and improved $\mathrm{BIC}^{\oplus}$ ballpoint pen, patented by French entrepreneur Marcel Bich (himself an Italian-born migrant, after whom the pen is named), which has monopolised the sector (Bicworld, 2019) and the collective French imagination. Having sponsored major national events, such as the Tour de France, and launched omnipresent advertising campaigns in France from the 1950s onwards, the $\mathrm{BIC}^{\circledast}$ brand is synonymous with French writing and schooling practices. Once again, therefore, we observe a material-symbolic, trans-national fusion indicative of the blogger's cultural identity transitioning.

Referring now to the 2012 and 2014 captures of the Lost in London and Londres Calling blogs (Figs. 4 and 5), further semiotic transmutations are noticeable. There are significant changes to both blog banners and a shared reliance on graphicnovel type visuals consistent with the blogging practices of the London-French community more widely (Huc-Hepher and Wells, 2021). This intertextual connectivity feeds into a broader trans-blog meaning-making and memory-making process, conceivable as a means of praxial community building. As Appadurai posits, 'the migrant archive is a continuous and conscious work of the imagination, seeking in collective memory an ethical basis for the sustainable reproduction of cultural identities in the new society' $(2019$, p. 563$)$. The common pictographic identity of the blogs therefore works on multiple semiotic levels simultaneously. Its figurative Londonness and formal Frenchness situates the blogs in a fertile cultural in-between space. Meanwhile, the agentive production, reproduction and circulation of shared stylistic resources allow the bloggers to 'use blogs not only as texts but also as avatars, performing gender and identities through blog iconography and signalling group identity and subcultural affiliations through engagement with specific blog design styles' (Vaisman, 2016, p. 294). The graphic-novel-style banners thus situate the blogs in a remembered French cultural space, where comic strips are celebrated as the ninth art (Huc-Hepher, 2016).
At the same time, they connect the bloggers to the LondonFrench (diasber)space through their shared in-betweenness and common culturally sensitised and locally emplaced referents (see Huc-Hepher, 2021; Tagg and Lyons, 2021).

Equally relevant here is the fluid and fecund seeping between languages and mixing of linguistic juices to produce and reproduce-from one blog to the next within the London-French blogosphere-a new trans, London/English/French body. This digital communicational conception could be seen, therefore, to play out XF anti-naturalist ideals, inasmuch as the women bloggers' computational creativity arguably queers natural reproduction through its technical, intertextual and translingual (re)productiveness (Laboria Cuboniks, 2015). Such digitised transcreation is identifiable in the navigation menu tabs in Fig. 4, which now merge French and English, 'A propos' having transitioned to 'About' and a 'F.A.Q.' (Frequently Asked Questions) option having emerged. Perhaps more indicative of the creative potential of the blogger's translanguaging is the title of the 2012 blogpost, 'Alfies [sic] Antique Market: des puces et un rooftop'. The French and English, as well as the on-line and on-land, are in conversation with each other: the reference to 'puces' (fleas) speaks of French 'flea markets', whereas 'rooftop' alludes to the 'placial' (Gieles, 2009, p. 276) lived experience of the London market and the blogger's quotidian immersion in the English language. The predominance of monolingual French language in the earlier snapshots has transformed into a translingual body, taking Pride in its transcultural, transplacial identity.

This is evinced yet more compellingly in a 2017 archived instance of the Lost in London blog-body (captured on 08 April). In a post about venturing to Tooting to sample the gastronomic delights of a French restaurant called Bordelaise, the blogger writes: 'Y retourner? Si j'étais "local" as we say around here, certainement. Et sûrement pour tester leur French Sunday roast.' Here, we note the distinctly and increasingly queer culturolinguistic positioning of the blog(ger). Comparable to the language used on social networking sites, this 'sits somewhere between personal conversation and public broadcasts' (Tagg and Seargeant, 2014, p. 161), and hence recalls the in-betweenness of the private/public (we)blog genre/gender and the archive more generally (Derrida, 1995). Despite being for public consumption, 


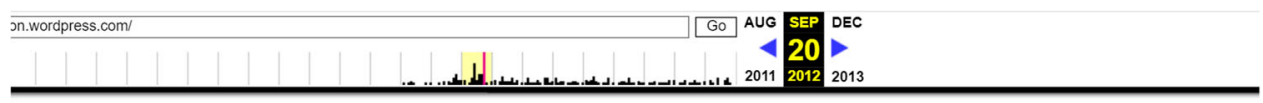

\section{Lost in London}

Blog sur Londres: pépites, adresses, découvertes et autres trésors.

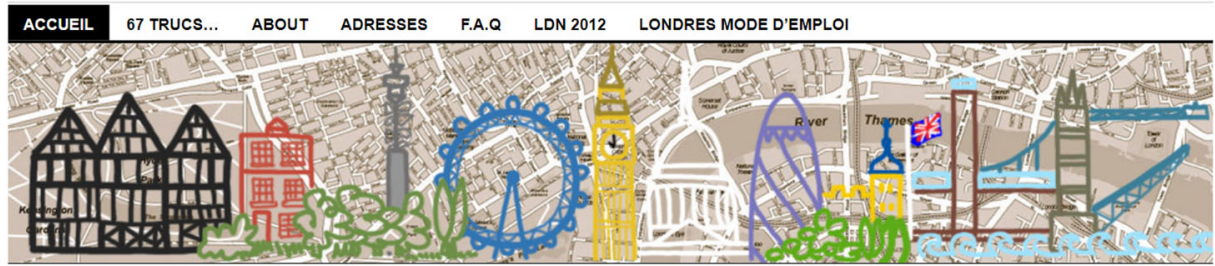

Alfies Antique Market: des puces et un rooftop Publié le 19 Septembre $2012 \mid 10$ commentaires

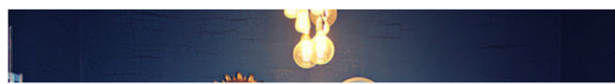

MOLESKINE

\& Roll on Sunday: Downton Abbey sur ITV

\& Jai découvert une nouvelle série super chouette: Parade's End

Fig. 4 Lost in London homepage, archived 20 September 2012. The banner has again been redesigned: the photographs have been replaced by a semiotically complex 'drawing' and the tabs now merge French and English. This figure is not covered by the Creative Commons Attribution 4.0 International License. Reproduced with permission of Fabienne Henry; copyright (cFabienne Henry, all rights reserved.
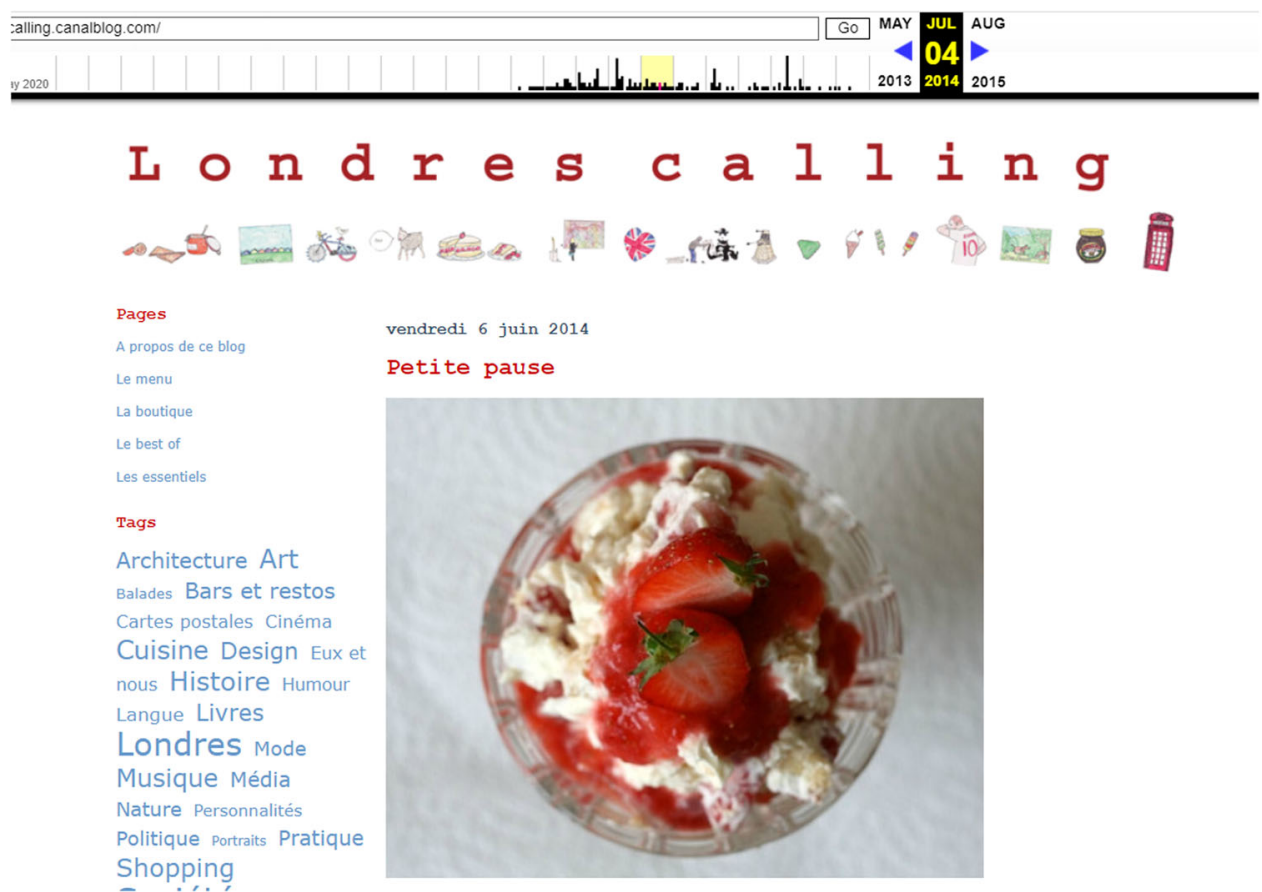

Fig. 5 Londres Calling blog landing page, archived 04 July 2014. The original telephone-booth banner has been replaced by a culturally sensitised graphic-novel-style suite of images that connect it to the London-French blogosphere and embed it in a transnational space. This figure is not covered by the Creative Commons Attribution 4.0 International License. Reproduced with permission of Léa Teuscher; copyright Clondrescalling.blog, all rights reserved.

the colloquial tenor of the utterance is perceptible through the rhetorical question and its inner-conversation quality. However, yet more striking is the spontaneous intermingling of French and English that effortlessly embodies London-French interactions on-land. We note the transition from French to English within the same sentence in accordance, it would appear, with the blogger's stream of consciousness. It seems the English term 'local' has been used almost pre-reflexively for its economy of effort, constituting a concept that would require several words in French. Yet, its use triggers a subsequent thought process in idiomatic, spoken-sounding English: 'as we say around here'. The unthinking character of this translanguaging is underlined by the absence of quotation marks, unlike "local"', which significantly now has the English rather than the French version of the punctuation (noted in Fig. 1). The blogger then reverts to French momentarily, before concluding in English with 'French Sunday roast'; 'tester', on the other hand, is positioned somewhere between the two languages and at a translingually pivotal point in the utterance.

Such fluid translanguaging goes beyond 'code-switching' (Androutsopoulos, 2013; Li, 2018), primarily because it is part of a wider multimodal body, as explored above, but also because of the simultaneous merging of cultures and blurring of place. The 'Sunday roast' concept is profoundly entrenched in British home-making 
and social-dining practices, so to preface it with 'French' is arguably a transgressively queering act. The simultaneous presence of eight English words and nine French, together with one 'in-betweener', melded in a single three-sentence utterance is equally transinclusive. We are now a long way from the contrived interlingual playfulness brought to bear in the early incarnations of the blogs, and closer to an intrinsically trans body that blends, blurs and 'troubles' linguistic, national and cultural divides.

Even the blogger's reference to 'local' (i.e. to Tooting) transcends the networked 'translocalism' described by Jannis Androutsopoulos (2006) and the binary conception of culture alluded to by Daniel Miller (2010). True to XF objectives, the localism evoked by the blogger is not a generic London-French one entangled with problematic boundary-building notions of-wealthy, white, South Kensington-'community', but a more emplaced localism that, through the insider's gaze, is capable of distinguishing between socio-culturally nuanced and highly situated places. In the blogger's hyperlocalised 'think[ing] beyond the [classed London-French] microcommunity' (Laboria Cuboniks, 2015, 0x0A) and my own efforts to depart from the essentialising construction of English as a global lingua franca favouring inclusivity and, by extension, diametrically opposed to 'other' languages which 'function as a strategy for addressing a particular language community' (Tagg and Seargeant, 2014, p. 182), we witness the rational performativity of an XF agenda. Granted, such organic translanguaging will speak to French residents in London more clearly than French 'stayers' (Favell, 2008, p. ix), but it will not necessarily resonate with members of the 'established' French 'community', whom, by their own admission, living in 'South Ken .... no longer see any English people or speak English at all' and 'could have left here [London] without knowing how to speak English' (Chantal). Furthermore, this translingual diasporic presence in the anglophone UK Web Archive actively breaks with the policy of other collections in the British Library, such as its Sound Archive's oral history repository, whose 'criteria for deposit ... [require that] the vast majority of the material is in English' (2011, private correspondence) ${ }^{16}$ Rather than an expression of communitarian exclusivity, therefore, the blogger's translanguaging is an incarnation of inclusivity (Cacciatore and Pepe, 2019). Beyond the splitting and othering (Hall, 1997) implicitly inscribed by notions of community and culture, and consequently by the hybridity construct, based on binaries of 'sameness and difference' (Appadurai 1990; Lawler, 2008) and reliant on 'residual elements of essentialization and culturalism' (Anthias, 2018, p. 136), the blog embodies an inoculating trans-fusion of languages, modes, cultures, spatialities and temporalities that together queer the corpus, the 'community' and the archive.

The evolving technical affordances of the blog platforms (Domingo et al., 2015) mean that more recent versions of Londres Calling and Lost in London are linguistically less obviously transblog-bodies.

Captures from $2018^{17}$ and 2019 reveal a predominance of visual meaning-making, whereby the Londres Calling landing page has been reinvented as a 12-part image-grid gallery, almost devoid of written text. Similarly, the Lost in London homepage (Fig. 6), now presents six full-screen, auto-rotating photographs. Both sites provide the blog visitor with greater visually facilitated navigational agency, but in so doing they fundamentally retransform the blogs. There are remnants of their previous incarnations, such as the distinctive red font used in Londres Calling or the enticing (French) wording of Lost in London's subtitle, but a priori their metaphorically trans identity seems somewhat compromised by these new, technologically motivated, orchestrations. Conversely, from an XF perspective, the bloggers' manipulation of the tech to repurpose the original (we)b-log/ diary form more patently than in the early, date-based presentation of posts could be regarded as an articulation of growing trans-feminist ideologies. Equally telling, as regards the migrants' sense of belonging and positioning in the London space and post-'Brexit'-EU mobility more broadly, is that the lostandfoundinlondon.wordpress.com URL has itself migrated to lostinlondon.fr. This arguably regressive establishment of nationbased TLD bordering thus mirrors the increasingly divided, nativist populism currently fracturing the transcultural, transnational European body and, by extension, the UK Web Archive; for the frr reincarnation of the blog will, without curatorial intervention, henceforth be excluded from the LFSC.

In this section, I have demonstrated how blog design, down to the ostensibly most insignificant typographical decisions, ought not be approached 'as an abstract sign system, but as a situated code choice, which is always part of a specific genre in a specific communicative situation' (Vaisman, 2011, p. 179). In this light, the archived web is not necessarily one of omnipresent borders and dichotomies, but one of progressive semiotic trans-mutation.

\section{A conclusive XF antidote to the mal d'archive}

Through the different sections of this article, I have demonstrated the multiple ways in which diasporic web collections queer the archive. Reading 'between the lines' and between modes, I have

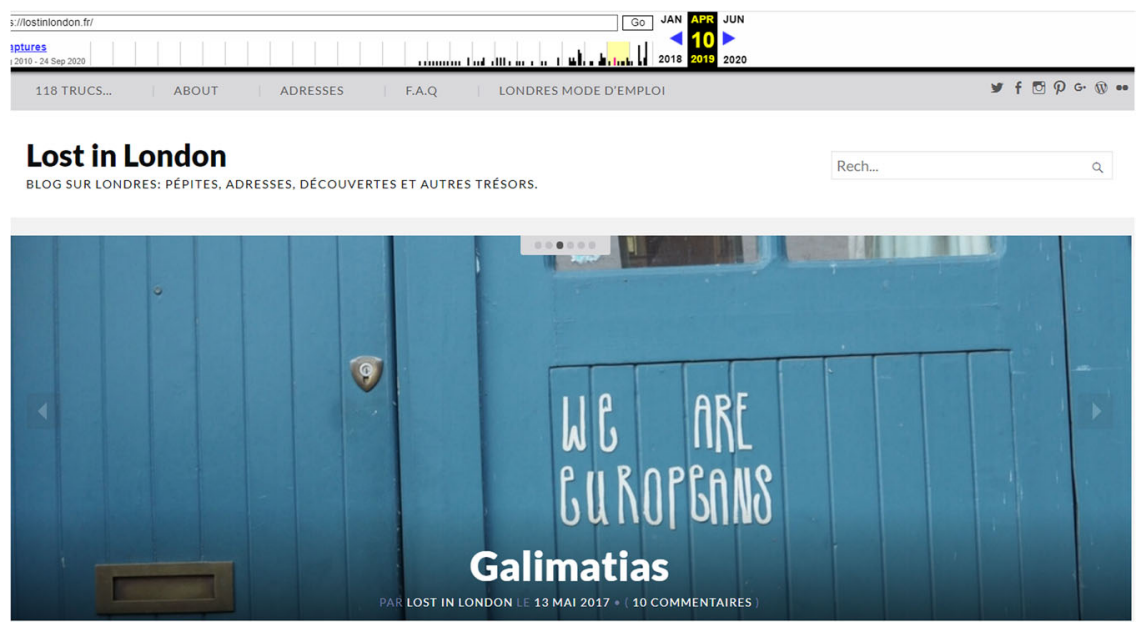

Fig. 6 Lost in London, archived 10 April 2019. Screenshot of the pared down landing page. The banner has been removed and six auto-rotating photographs fill the screen in succession. This figure is not covered by the Creative Commons Attribution 4.0 International License. Reproduced with permission of Fabienne Henry; copyright (CFabienne Henry, all rights reserved. 
teased out meaning from the in-between space of French migrant women's blogs, showing how their progressive spatiotemporal, cultural and linguistic queering dovetails with 'a xenofeminist politics of technology' (Hester, 2018, p. 149). Repurposing their blogs to their own expressive and commercial ends, the blog(ger)s were seen to destabilise established notions of gender and genre, while their increasingly spontaneous translanguaging practices went against the grain of standardised monolingualism, itself a relic of empire, white (male) supremacy and heteronormativity. The article has thus challenged the artificial boundaries that continue to compartmentalise contemporary archiving practices and intradisciplinary scholarship more broadly.

Indeed, rather than apprehending generic and gendered transformation as a 'troubling' disorder, symptomatic of the Freudian mal d'archive evoked by Derrida (1995), this paper has highlighted its disruptive potency, revealing it to be a force for good not ill. In this way, I have responded creatively to the XF call for 'a feminism at ease with computation' and which 'understands that the viability of emancipatory abolitionist projects-abolition of class, gender, and race-hinges on a profound reworking of the universal' (Laboria Cuboniks, 2015, 0×07, 0x0F). I have argued that this crucial sense of inclusive universality is characterised figuratively by the trans body, whether in the form of the LFSC as a unified, yet culturolinguistically 'other' and generically plural corpus; whether in the methodological unification played out by the transdisciplinary ethnosemiotic approach and inherent in-betweenness of multimodality; whether in the (re)purposeful creativity and translanguaging of the LondonFrench blog-body; whether in the web archive, as an overarching whole, whose simultaneous incorporation of multilingual migrant minority websites and (trans)national reach pave the way for a progressive diversified unity; or whether in the women curators of the diasporic web collections and London-French bloggers themselves, whose constructive embodiment of otherness is testament to their embracing of XF ideals.

In an age characterised by increasing divisions and xenophobia, the legitimacy and urgency of xenofeminist work is irrefutable. It is hoped that this paper has made a small, but significant, contribution to that collective enterprise.

\section{Data availability}

The interview data presented in this study are not publicly available due to restrictions in data collection policy and to protect participant anonymity. However, the digital data (blog screenshots) are publicly available via the UK Web Archive and/ or the Internet Archive and are published in this article with the permission of the copyright holders.

Received: 23 October 2020; Accepted: 3 November 2021; Published online: 25 November 2021

\section{Notes}

1 I have chosen not to use the term 'womxn' in this paper owing to the negative response it has received elsewhere (e.g. in 2018 when used by the Wellcome Trust to promote their archival zine workshops) and in recognition of opposition from trans and non-binary people, who find the term exclusionary and offensive rather than inclusive (as set out here).

2 Other diasporic corpora in the UK Web Archive curated by multilingual women include the Latin America UK collection curated by Naomi Wells, the Russia in the UK collection curated by Hannah Connell, and the East and South East Asian in the UK collection currently being curated by Xiao Ma, a doctoral candidate and firstgeneration woman migrant from China. There are also important collections dedicated to Black and Asian Britain, Caribbean Communities in the UK and to the Government in Wales/Llywodraeth yng Nghymru, one of the few bilingual collections.
3 The term 'tacitly' is important here, as the current UK Web Archive senior leadership team is composed of women, who are proactively open to the incorporation of diasporic Special Collections and welcome their queering potential. The idea of the 'patri-archive' thus corresponds to the implicit legacy of centuries of white, male, monolingual domination in such institutional structures as national archives, rather than the contemporary 'xeno'-inclusive, xenofeminist even, management at the UKWA.

4 The seed of this article was planted during a keynote presentation by Megan Sapnar Ankerson at the 2019 RESAW Conference in Amsterdam, The web that was: archives, traces, reflections, and I am indebted to the speaker for the initial inspiration.

5 It is worth noting that the xenofeminist lens I apply in this paper is a retroactive construct, borne of the thinking and reading I have done since initially curating the LFSC. For details of the theoretical approach taken at the outset (see Huc-Hepher, 2015).

6 In an online seminar titled 'Doing Feminist Thinking: A Conversation with Professor Judith Butler', hosted by the University of Oxford on 28 May 2021, Butler underlined the importance of taking a transregional, translingual and transdisciplinary stance to counter increasingly mainstream and globalised far-right rhetoric (such as the French islamo-gauchiste anti-Critical Race Theory discourse, which misleadingly apprehends CRT as an imported monolithic threat to the nation). Significantly, Butler welcomed the multiple, sometimes conflicting interpretations of her work on transgender bodies and identities, deeming current reworkings and reapplications of ideas formulated some three decades earlier as fundamentally positive, even when the original contention had been misunderstood. It is in this experimental and (re)generative vein that I apply queer, feminist and trans-inclusive xenofeminist theory to an unlikely object of study: the web archive.

7 The country code Top-Level Domain (ccTLD) is an internet space whose code (such as.uk or.fr) typically corresponds to a nation state. Consequently, physical geographic borders find themselves re-erected in the webosphere and subsequently in national collecting institutions, where the legal and technical frameworks that govern them further entrench these national, and by extension linguistic, divides. In the case of the UK Web Archive, the result is that it 'includes only web resources published in the UK. This means all websites ending in .uk, .scot, .wales, .cymru and .london, and any website hosted on a server based in the UK' (British Library, no date). These national delimitations of archival space necessarily exclude any diasporic material hosted by domains outside the 'territory', such as the .coms of (US-based) blogging and social media platforms (Bingham and Byrne, 2020) or the .fr sites of transnationally positioned publications. However, the permission-based, curatorial intervention associated with selective micro-archives, like the LFSC and other diasporic corpora in the UK Web Archive, enables the incorporation of web resources from a range of domains outside the UK, including, for example, .fr, .eu, .com and .org, which in turn contributes to the inclusiveness of the UKWA and the queering potential of its diasporic collections.

8 The authors illustrate these power imbalances with a crawl of the African web in 2002 that harvested only 2 million web pages-derisory compared to the size of the continent-and 'almost $75 \%$ of these were in English, which is spoken as a first language by far less than $1 \%$ of the African population' (Schroeder and Brügger, 2017, p. 4).

9 By making this comparison I do not intend to equate the lived experience of People of Colour with (white) French nationals, since white privilege and the long history of oppression to which the former have been subjected evidently distinguish both groups. However, the role of right-wing media in perpetuating stereotypes and fuelling antagonism is considered analogous.

10 As a qualified translator, I have translated all primary and secondary French sources into English.

11 The universal access to knowledge sought by the US-based Internet Archive is a model currently irreplicable by the UK Web Archive, where compliance with the 2013 Non-Print Legal Deposit Regulations is a profound barrier to access. The legislation has the advantage of allowing the British Library 'to take a copy of any UK digitally published resource (including websites and social media)' (British Library, no date), but the disadvantage of making the archived copies thereof publicly available in only six UK Legal Deposit Libraries (where physical access, for the purpose of onsite consultation alone, is further restricted by the need for registration and reader passes). However, the benefit of its curated collections, including the LFSC, is that permission is sought from the owner of each selected web object with an aim to guarantee open access to all via the World Wide Web.

12 I apprehend 'posthumanist' according to the framing established by Helen Hester 'as a deliberate blurring of the distinctions at the edges of the species - that is, around the boundaries between ourselves and inanimate objects (such as technological devices)' (2019, p. 68), but acknowledge that this understanding is at odds with Donna Haraway's anthropocentric rejection of posthumanism (2016).

13 Today, the gender variable among French migrants in the UK is far more balanced. 14 I conducted this interview and the other one quoted in the article in London between May 2011 and July 2012. For full methodological details and interviewee profiles, see Huc-Hepher (2021). Note that interviewees have been given pseudonyms to protect their anonymity. 
15 It is important to note that despite blogs being equipped with in-built archives, changes made to their design or functional affordances are lost with each iteration of the site. It is only by consulting past instances of the blogs preserved in web archives that these semiotically meaningful changes become visible and analysable; hence the scientific and historic value of internet archives.

16 Quoted from personal email correspondence with a representative of the British Library whose identity shall remain anonymous.

17 For an example of the 2018 Londres Calling image gallery format, see https:// web.archive.org/web/20180103190446/https://londrescalling.blog/

\section{References}

Abutbul-Selinger G (2018) Invisible boundaries within the middle class and the construction of ethnic identity. Identities. https://doi.org/10.1080/ 1070289X.2018.1520448

Ahmed S (2015) You are oppressing us! Feminist killjoys. https:// feministkilljoys.com/2015/02/15/you-are-oppressing-us/

Ames S, Lewis S (2020) Disrupting the library: digital scholarship and Big Data and the National Library of Scotland. Big Data Soc Jul-Dec: 1-7. https://doi.org/ $10.1177 / 2053951720970576$

Androutsopoulos J (2006) Multilingualism, diaspora, and the internet: Codes and identities on German-based diaspora websites. J Socioling 10(4):520-547

Androutsopoulos J (2013) Code-switching in computer-mediated communication. In: Herring SC, Stein D, Virtanen T (eds) Handbook of the pragmatics of CMC. Mouton de Gruyter, Berlin, pp. 667-694

Ankerson MS (2011) Writing web histories with an eye on the analog past. New Media Soc 14(3):384-400. https://doi.org/10.1177/1461444811414834

Ankerson MS (2019) Zombies, robots and time machines. Paper presented at the 3rd international RESAW conference on The Web that Was: archives, traces, reflections. University of Amsterdam, Amsterdam, 19-21 June 2019

Anthias F (2018) New hybridities, old concepts. In: Stierstorfer K, Wilson J (eds) The Routledge diaspora studies reader. Routledge, London \& New York, pp. 133-138

Appadurai A (1990) Disjuncture and difference in the global cultural economy. Theory Cult Soc 7:295-310. https://doi.org/10.1177/026327690007002017

Appadurai A (2019) Traumatic exit, identity narratives, and the ethics of hospitality. Telev New Media 20(6):558-565. https://doi.org/10.1177/1527476419857678

Asenbaum H (2019) Rethinking digital democracy. Commun Theory. https:// doi.org/10.1093/ct/qtz033

BBC (2005) WW2 people's war: an archive of World War Two memories. https:// www.bbc.co.uk/history/ww2peopleswar/stories/60/a4401460.shtml Accessed 21 July 2020

Barthes R (1980) La chambre claire: notes sur la photographie. Gallimard, Paris

Beauvoir (de) S (1979) Le Sexisme ordinaire. Le Seuil, Paris

Bellion G (2005) French business in the UK-a survey. Dissertation, Université de Franche-Comté

Ben-David A (2021) Critical web archive research. In: Gomes D, Demidova E, Winters J, Risse T (eds) The past web: exploring web archives. Springer, Cham, pp. 181-188

Bicworld (2019) Notre héritage, votre passion. https://www.bicworld.com/fr/apropos-de-nous/notre-heritage-votre-passion. Accessed 21 Jul 2020.

Bingham N, Byrne H (2020) Archival strategies for contemporary collecting in a world of big data: challenges and opportunities with curating the UK web archive. Big Data Soc 1-6. https://doi.org/10.1177/2053951721990409

Bonacchi C, Krzyzanska M (2019) Digital heritage research retheorised: ontologies and epistemologies in a world of big data. Int J Herit Stud 25(12):1235-1247. https://doi.org/10.1080/13527258.2019.1578989

Bourdieu P ([1972]2000) Esquisse d'une théorie de la pratique. Le Seuil, Paris

Boyd D (2008) Taken out of context: American teen sociality in networked publics. Dissertation, University of California-Berkeley

British Library (no date) Collection Guides. https://www.bl.uk/collection-guides/ uk-web-archive\#. Accessed 14 Oct 2021

Brügger N (2012) When the present web is later the past. Hist Soc Res 37(4):102-17. https://doi.org/10.12759/hsr.37.2012.4.102-117

Butler J (1988) Performative acts and gender constitution: an essay in phenomenology and feminist theory. Theatre J 40(4):519-531

Butler J (1990) Gender trouble: feminism and the subversion of identity. Routledge, Abingdon \& New York

Butler J (1993) Bodies that matter: on the discursive limits of "sex". Routledge, Abingdon \& New York

Cacciatore F, Pepe G (2019) Performing new identities: the community language of post-crisis Italian migrants in London. Natl Identities 21:507-526

Conradson D, Latham A (2007) The affective possibilities of london: antipodean transnationals and the overseas experience. Mobilities 2(2):231-254. https:// doi.org/10.1080/17450100701381573

Cooke T (2001) “Trailing wife" or "trailing mother"? Environ Plan A 33(3):419-430

Costa M (2021) Full-text and URL search over web archives. In: Gomes D, Demidova E, Winters J, Risse T (eds) The past web: exploring web archives. Springer, Cham, pp. 71-84
Criado Perez C (2019) Invisible women: exposing data bias in a world designed for men. Chatto Windus, London

Das S, Lowe M (2018) Nature Read in Black and White: decolonial approaches to interpreting natural history collections. J Nat Sci Collect 6:4-14. http:// www.natsca.org/article/2509

Derrida J (1995) Mal d'archive: Une impression freudienne. Editions Galilée, Paris

Domingo M, Jewitt C, Kress G (2015) Multimodal social semiotics: writing in online contexts. In: Pahl K, Rowsell J (eds) The Routledge handbook of literary studies. Routledge, Abingdon

Edelman L (2004) No future: queer theory and the death drive. Duke University Press, Durham

Farrer J (2010) 'New Shanghailanders' or 'New Shanghainese': Western expatriates' narratives of emplacement in Shanghai. J Ethn Migr Stud 36(8):1211-1228

Favell A (2008) Eurostars and Eurocities. Blackwell, Oxford

Fiormonte D, Numerico T, Tomasi F, Schmidt D, Ferguson C (2015) The digital humanist: a critical enquiry. Punctum Books, Santa Barbara. https:// www.jstor.org/stable/j.ctvlbd4hbj

Fiske J (1990) Ethnosemiotics: some personal and theoretical reflections. Cult Stud 4(1):85-99. https://doi.org/10.1080/09502389000490061

Fuchs C (2017) From digital positivism and administrative big data analytics towards critical digital and social media research! Euro J Commun 10(2):37-49. https://doi.org/10.1177/0267323116682804

Flanagan M (2013) The bride stripped bare to her data: information flow + digibodies. In: Keilty P, Dean R (eds) The feminist and queer information studies reader. Litwin Books, Sacramento, pp. 13-47

Flanagan M (2002) Hyperbodies, hyperknowledge: women in games, women in cyberpunk, and strategies of resistance. In: Flanagan M, Booth A (eds) Reload: rethinking women+cyberculture. MIT Press, Boston, pp. 444-447

Foucault M (1969) L'archéologie du savoir. Gallimard, Paris

Gomes D (2021) The era of information abundance and memory scarcity. In: Gomes D, Demidova E, Winters J, Risse T (eds) The past web: exploring web archives. Springer, Cham, pp. 1-3

Giannakoulopoulos A, Pergantis M, Konstantinou N, Lamprogeorgos A, Limniati L, Varlamis I (2020) Exploring the dominance of the English language on the websites of EU countries. Futur Internet 12(4):76. https://doi.org/10.3390/ fi12040076

Gieles R (2009) A global sense of migrant places: towards a place perspective in the study of migrant transnationalism. Glob Netw 9(2):271-387. https://doi.org/ 10.1111/j.1471-0374.2009.00254.x

Hall S (1997) The spectacle of the other. In: Representation: cultural representations and signifying practices. Sage, with the Open University, London, pp. 223-290

Halperin DM (1995) Saint Foucault: towards a gay hagiography. Oxford University Press, New York

Hansen M (2007) Bodies in code: interfaces with digital media. Routledge, New York Haraway D (1984) Teddy bear patriarchy: taxidermy in the Garden of Eden, New York City, 1908-1936. Soc Text 11:20-64. https://doi.org/10.2307/466593

Haraway D (1991) A Cyborg Manifesto: science, technology, and socialistfeminism in the late twentieth century. In: Simians, Cyborgs and Women: the reinvention of nature. Routledge, New York, pp. 149-181

Haraway D (2016) Staying with the trouble: making kin in the chthulucene. Duke University Press, Durham

Hester H (2015) Synthetic genders and the limits of micropolitics. CORE, University of California

Hester H (2018) Xenofeminism. Polity, Cambridge

Hester H (2019) SAPIENCE+CARE. Angelaki 24(1):67-80. https://doi.org/ 10.1080/0969725X.2019.1568734

Hine C (2015) Ethnography for the Internet. Bloomsbury, London

Huc-Hepher S (2015) Big Web data, small focus: an ethnosemiotic approach to culturally themed selective Web archiving. Big Data Soc 2(2):1-15. https:// doi.org/10.1177/2053951715595823

Huc-Hepher S (2016) The material dynamics of a London-French Blog: a multimodal reading of migrant habitus 1-30. Mod Lang Open. https://doi.org/ $10.93828 / \mathrm{mlo} . \mathrm{v} 0 \mathrm{i} 0.91$

Huc-Hepher S (2019) “Sometimes there's racism towards the French here”: xenophobic microaggressions in pre-2016 London as articulations of symbolic violence. Nat Identities 23(1):15-39. https://doi.org/10.1080/14608944.2019.1649250

Huc-Hepher S (2021) French London: a blended ethnography of a migrant city. Manchester University Press, Manchester

Huc-Hepher S, Wells N (2021) Exploring online Diasporas: London's French and Latin American Communities in the UK Web Archive. In: Gomes D, Demidova E, Winters J, Risse T (eds) The past web: exploring web archives. Springer, Cham, pp. 189-201

Inghilleri M (2016) Translation and migration. Routledge, Abingdon

Internet Archive (no date) About the Internet Archive. https://archive.org/about/. Accessed 14 Oct 2021

Jewitt C (2011) The Routledge handbook of multimodal analysis, 1st edn. Routledge, Abingdon 
Johnson R (2018) Queering/querying the body: sensation and curiosity in disrupting body norms. In: Caldwell C, Leighton LB (eds) Oppression and the body: roots, resistance, and resolutions. North Atlantic Books, Berkley, pp. 97-111

Kitchin R (2014) The Data Revolution: big data, open data, data infrastructures \& their consequences. SAGE, London

Kress G (2010) Multimodality. A social semiotic approach to contemporary communication. Routledge, Abingdon \& New York

Kress G (2011) Partnerships in research: multimodality and ethnography. Qual Res 11(3):239-260. https://doi.org/10.1177/1468794111399836

Kusters A (2021) Introduction: the semiotic repertoire: assemblages and evaluation of resources. Int J Multiling 18(2):183-189. https://doi.org/10.1080/ 14790718.2021 .1898616

Kusters A, Spotti M, Swanwick R, Tapio E (2017) Beyond languages, beyond modalities: transforming the study of semiotic repertoires. Int J Multiling 14(3):219-232. https://doi.org/10.1080/14790718.2017.1321651

Laboria Cuboniks (2015) Xenofeminism: a politics for alienation. https:// laboriacuboniks.net/manifesto/xenofeminism-a-politics-for-alienation/ Accessed 17 July 2020

Lawler S (2008) Identity: Sociological Perspectives. Polity, Cambridge

Levin I (2016) Migration, settlement, and the concepts of house and home. Routledge, Abingdon \& New York

Li W (2011) Moment Analysis and translanguaging space: discursive construction of identities by multilingual Chinese youth in Britain. J Pragmat 43(5):1222-1235. https://doi.org/10.1016/j.pragma.2010.07.035

Li W (2018) Translanguaging as a practical theory of language. Appl Linguist 39(1):9-30. https://doi.org/10.1093/applin/amx039

$\mathrm{Lu} \mathrm{H}$ (2002) Nostalgia for the future: the resurgence of an alienated culture in China. Pac Aff 75(2):169-186

Lulle A, Moroşanu L, King R (2018) And then came Brexit: Experiences and future plans of young EU migrants in the London region. Popul Space Place 24:e2122. https://doi.org/10.1002/psp.2122

McMillan U (2015) Embodied avatars: genealogies of black feminist art and performance. New York University Press, New York

Miller D (2010) Stuff. Polity Press, Cambridge

Milligan I (2019) History in the age of abundance. McGill-Queen's University Press

Mizumura M (2015) The fall of language in the age of English. Columbia University Press, New York

Mulholland J, Ryan L (2017) London is a much more interesting place than Paris: place comparison and moral geographies of highly skilled migrants. In: Van Riemsdijk M, Wang Q (eds) Rethinking international skilled migration. Routledge, London

Ogden J, Halford S, Carr L (2017) Observing Web Archives: The Case for an Ethnographic Study of Web Archiving. In: Proceedings of the 2017 ACM on Web Science Conference (WebSci '17). Association for Computing Machinery, Troy, NY, USA. June 25-28, 2017, pp. 299-308. https:// dl.acm.org/doi/10.1145/3091478.3091506

Ogden J, Maemura E (2021) 'Go fish': conceptualising the challenges of engaging national web archives for digitial research. Int J Digit Humanit 1-21. https:// doi.org/10.1007/s42803-021-00032-5

Parker D, Song M (2007) Inclusion, participation and the emergence of British Chinese websites. J Ethn Migr Stud 33(7):1043-1061. https://doi.org/10.1080/ 13691830701541564

Phipps A (2020) Me, not you: the trouble with mainstream feminism. Manchester University Press, Manchester

Pink S, Ruckenstein M, Willim R, Duque M (2018) Broken data: conceptualising data in an emerging world. Big Data Soc 5(1):1-13. https://doi.org/10.1177/ 2053951717753228

Pitman T (2018) Warriors and weavers: the poetics and politics of indigenous appropriations of new media technologies in Latin America. Mod Lang Open 1-14. https://doi.org/10.3828/mlo.v0i0.207

Pot'Vin-Gorman K (2019) Crushing the IT gender bias: thriving as a woman in technology. Apress, Berkeley

Rao R (2020) Out of time: the queer politics of postcoloniality. Oxford University Press, New York

Ravelli LJ, van Leeuwen T (2018) Modality in the Digital Age. Vis Commun 17(3):277-297. https://doi.org/10.1177/1470357218764436

Rieder B, Abdulla R, Poell T, Woltering R, Zack L (2015) Data critique and analytical opportunities for very large Facebook pages: lessons learned from exploring 'we are all khaled said'. Big Data Soc 2(2):1-22. https://doi.org/ $10.1177 / 2053951715614980$

Rowsell J (2011) Carrying my family with me: artifacts as emic perspectives. Qual Res 11(3):331-346. https://doi.org/10.1177/1468794111399841

Sassen S (2013) Does the city have speech? Public Cult 25(2):209-221. https:// doi.org/10.1215/08992363-2020557

Schroeder R, Brügger N (2017) Introduction: the web as history. In: Schroeder R, Brügger $\mathrm{N}$ (eds) The Web as history: using web archives to understand the past and the present. UCL Press, London, pp. 1-19

Shilling C (2016) The rise of body studies and the embodiment of society: a review of the field. Horizons Humanit Soc Sci 2(1):1-14
Singh R (2012) Crowdsourced geospatial data. GIM Int 26(9):26-31

Skowronsk GA (2015) Pain relief in childbirth: changing historical and feminist perspectives. Anaesth Intensiv Care-Hist Suppl 25-28. https://doi.org/ 10.1177/0310057X150430S106

Stockdale A (2016) From "trailing wives" to the emergence of a "trailing husbands" phenomenon. Popul Space Place 23(3):1-18. https://doi.org/10.1002/psp.2022

Tagg C, Seargeant P (2014) Audience design and language choice in the construction and maintenance of translocal communities on social network sites. In: Seargeant $\mathrm{P}$, Tagg C (eds) The language of social media: identity and community on the Internet. Palgrave Macmillan, London and New York, pp. 161-185

Tagg C, Lyons A (2021) Repertoires on the move: exploiting technological affordances and contexts in mobile messaging interactions. Int J Multiling 18(2):244-266. https://doi.org/10.1080/14790718.2020.1867150

Thompson TL (2020) Data-bodies and data activism: presencing women in digital heritage research. Big Data Soc Jul-Dec:1-7. https://doi.org/10.1177/ 2053951720965613

Thorburn ED (2017) Cyborg witches: class composition and social reproduction in the GynePunk collective. Fem Media Stud 17(2):153-167. https://doi.org/ $10.1080 / 14680777.2016 .1218353$

Tisseron S (2001) L'intimité surexposée. Ramsay, Paris

Vaisman C (2011) Performing girlhood through typographic play in Hebrew blogs. In: Thurlow C, Kroczek K (eds) Digital discourse: language in the new media. Oxford University Press, Oxford

Vaisman C (2016) Pretty in pink vs. pretty in black. Visual Commun 15(3):293-315. https://doi.org/10.1177/1470357216643909

Vannini P (2007) Social semiotics and fieldwork: method and analytics. Qual Ing 13(1):113-140. https://doi.org/10.1177/1077800406295625

Walsh K (2018) Transnational geographies of the heart. Wiley, Chichester/Oxford Wang C (2013) Place of desire: skilled migration from mainland China to post-colonial Hong Kong. Asia Pac Viewp 54(3):388-397. https://doi.org/10.1111/apv.12032

Webster P (2019) Understanding the limitations of the ccTLD as a proxy for the national web. In: Brügger N, Laursen D (eds) The historical Web and digital humanities. Routledge, London \& New York, pp. 110-123

Yuval-Davis N (2006) Belonging and the politics of belonging. Patterns Prejud 40(3):197-214

\section{Acknowledgements}

For kind permission to include screenshots of their blogs, I thank Fabienne Henry and Léa Teuscher; and for their thorough and thought-provoking feedback, I extend my sincere gratitude to the anonymous reviewers.

\section{Competing interests}

The author declares no competing interests.

\section{Ethical approval}

This study was performed in line with the principles of the Declaration of Helsinki, and approved by the Ethics Committee of the University of Westminster.

\section{Informed consent}

Informed consent was obtained from all subjects involved in this study.

\section{Additional information}

Correspondence and requests for materials should be addressed to Saskia Huc-Hepher.

Reprints and permission information is available at http://www.nature.com/reprints

Publisher's note Springer Nature remains neutral with regard to jurisdictional claims in published maps and institutional affiliations.

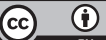

Open Access This article is licensed under a Creative Commons Attribution 4.0 International License, which permits use, sharing, adaptation, distribution and reproduction in any medium or format, as long as you give appropriate credit to the original author(s) and the source, provide a link to the Creative Commons license, and indicate if changes were made. The images or other third party material in this article are included in the article's Creative Commons license, unless indicated otherwise in a credit line to the material. If material is not included in the article's Creative Commons license and your intended use is not permitted by statutory regulation or exceeds the permitted use, you will need to obtain permission directly from the copyright holder. To view a copy of this license, visit http://creativecommons.org/ licenses/by/4.0/.

(C) The Author(s) 2021, corrected publication 2021 